MARIANA PEDRON MACÁRIO

\title{
JOSÉ CLEMENTE PEREIRA E O DEBATE JURÍDICO DO IMPÉRIO
}

$$
1830-1850
$$

DISSERTAÇÃo DE MESTRADO

ORIENTADOR: PROFESSOR ASSOCIADO JOSÉ REINALDO DE LIMA LOPES

FACUldade DE DiReito DA UniVERSIDAde DE SÃo PAUlo

SÃo PAULO

2011 


\title{
JOSÉ CLEMENTE PEREIRA E O DEBATE JURÍDICO DO IMPÉRIO
}

\author{
$1830-1850$
}

Dissertação apresentada como requisito parcial para a obtenção do título de Mestre, junto ao Departamento de Filosofia e Teoria Geral do Direito da Faculdade de Direito da Universidade de São Paulo

ORIENTADOR: PROFESSOR ASSOCIADO

JosÉ REINALDO DE LIMA LOPES

FACUldade DE DiReito DA UniVERSIDAde DE SÃo PAUlo

SÃO PAULO

2011 
Para Maria Tereza, minha mãe, e Sofia, minha filha 


\section{AGRADECIMENTOS}

Agradeço ao Professor José Reinaldo de Lima Lopes a oportunidade de ter sido sua orientanda. Seu rigor na investigação, sua busca por excelência e sua paixão pela história despertaram minha admiração desde que o conheci. Excepcional orientador, sua atenção e cuidado foram sempre ímpares, mesmo nos momentos mais atarefados de sua intensa vida acadêmica. Devo a ele mais do que os méritos - caso haja - dessa dissertação; foi graças aos seus cursos e aos seus escritos que mantive o interesse pelo direito como campo de investigação e atuação. Como professor, orientador e pensador, sempre manteve algo que para mim é essencial: uma visão do direito que não abre mão da reflexão sobre a justiça.

Aos Professores José Eduardo Faria e Cecília Helena Salles de Oliveira, que integraram minha banca de qualificação, agradeço a atenção e cuidado com que leram meu texto e às valiosíssimas sugestões que me fizeram. Mais do que isso, é preciso mencionar que eles estão presentes em minha vida acadêmica muito mais do que esse texto faz parecer, pois são para mim referências no direito e na história.

Aos funcionários da Faculdade de Direito do Largo São Francisco agradeço a gentileza e constante disposição em ajudar, indo sempre além de suas atribuições e acompanhando com interesse a trajetória dos alunos que com eles convivem. Faço-o nas pessoas do Eduardo Aguiar, Aurélio dos Santos, Mário Sérgio de Oliveira e Silva, Ana Lima Batista e Beatriz dos Santos, representando todos os outros.

Na minha rápida passagem pelo curso de História da Universidade de São Paulo conheci pessoas que me ajudaram a perseverar e mantiveram comigo um diálogo profícuo e uma convivência carinhosa. Ao Lincoln Secco, agradeço por ter sido um ótimo ouvinte e motivador e por ter me permitido integrar a irmandade braudeliana. Para os agradecimentos a João Paulo Garrido Pimenta e Andrea Slemian faltam palavras e sobram motivos: pelas conversas estimulantes, pelos conselhos acadêmicos e pessoais, pela acolhida sempre alegre e generosa. Admiro-os pelos historiadores que são e os estimo pelos amigos que se tornaram. 
Ao meu irmão Vinícius e aos meus amigos mais próximos agradeço o apoio constante, o estímulo bem humorado e a audiência atenta: a Marianna Sampaio, Luciana Zaffalon, Priscila Spécie, Silvia Naschenveng, Maria Virgínia Mesquita, Caroline Freitas, Nilce Tranjan, Danilo Tavares, Walter Hupsel e Tiago Tranjan. Amo-os também por me castigarem da forma mais carinhosa e divertida possível pelas ausências e esquecimentos, sempre me perdoando, afinal. Ao Leandro, que de tão longe nos deixa saudades e uma dúvida: se o que faz mais falta é o amigo de todas as horas ou o interlocutor perspicaz de minhas inquietações intelectuais.

Àqueles que, por diversas circunstâncias, não tem estado tão próximos fisicamente, mas foram importantes em um ou mais momentos dessa trajetória: Daniel Stain, Ester Rizzi, Alessandro Soares, Paulo Macedo Garcia Neto, Maria Paula Bertran, Natasha Caccia e André Payar. Aos colegas e parceiros: Fernanda Machiaveli, Wagner Orlandi, João Manoel S. de Barros, Ricardo Riquelme, Helena Romanach, Tatiana Whately, Marcelo Nardi, Roberta Sundfeld, Vittore Maximiano, Davi Depiné Filho e Gustavo Reis; foi graças a eles que essas jornadas múltiplas foram possíveis e mais amenas. Aos recentes e importantes interlocutores: Felipe de Oliva, Leonardo Rosa e Vivian C. Costa; à Vivian agradeço especialmente a ajuda que me deu na fase final do trabalho. A Mariana Rocha, agradável surpresa que este momento trouxe.

À minha família - avós, tios, primos, cunhados e sogros - agradeço imensamente a compreensão e a torcida sincera. Esses foram, certamente, os maiores objetos da minha ausência, mas foram também aqueles que mesmo sem conhecer a fundo as demandas da vida de um pós-graduando sempre a compreenderam e apoiaram.

Essa dissertação foi uma parte importante da minha vida nos últimos três anos, mas ela fica pequena demais para incluir os agradecimentos ao meu marido, Roberto, e aos meus pais, Aluizio e Maria Tereza. Pois muito mais do que me ajudar a fazer a dissertação que pude, eles me permitiram construir a vida que sonhei. São para mim exemplo de companheiro, de pai e de mãe, além de meus melhores amigos. As horas de convivência roubadas e os sacrifícios que fizeram por mim constituem uma dívida que nunca me cobraram; mas a eles faço a doce promessa de passar o resto da vida a saldála. 


\section{RESUMO}

O presente trabalho trata de alguns temas do debate jurídico da primeira metade do século XIX. Estes temas são analisados a partir da participação do magistrado e político José Clemente Pereira. É o momento do esforço de criação de uma legislação nacional, necessária em decorrência do rompimento dos laços com Portugal. Nascido em Portugal em 1787, formado em Coimbra, Clemente Pereira imigrou para o Brasil em 1815. Rapidamente ascendeu nos negócios e na carreira política, participando das articulações que levaram à independência e se tornando muito influente na capital fluminense em razão de negócios no mercado de gêneros de abastecimento e de sua atuação como advogado dos grandes comerciantes da Corte. Foi juiz de fora, deputado geral, ministro do império, da guerra e da marinha, senador, conselheiro de estado e presidente do primeiro Tribunal do Comércio do Brasil. A partir dessas posições participou e influenciou vários debates sobre temas políticos e jurídicos, entre os quais escolhemos três: a criação da lei de responsabilidade dos ministros de Estado, de 1827; os debates sobre o Código Criminal do Império, criado em 1830, e do Código Comercial, de 1850. Os debates mostram os desafios que estavam colocados para a formação do Estado e da nação brasileiros, num contexto de transformação do direito representado pelo moderno ideário de codificação, e mudanças na política, com a crescente centralização do poder monárquico, mas também com sua limitação a partir do advento do constitucionalismo.

Palavras-chave: José Clemente Pereira - Criação do direito nacional - Codificação - Código Criminal do Império - Código Comercial do Império - Formação do Estado - Constitucionalismo 


\begin{abstract}
This paper aims at discussing some aspects of the legal debate that took place during the first half of the XIXth Century. Said aspects are assessed from the moment Justice and Politician José Clemente Pereira appears in the public scenario. It is the moment when strengths are gathered to create a national legislation, then mandatory due to the rupture of bonds with Portugal. Born in Portugal in 1787, graduate at the University of Coimbra, Clemente Pereira immigrated to Brazil in 1815. He rapidly gained importance as a businessman and as a politician, taking part in the discussions that lead to the Independence and becoming quite influential in the Court due to his business and his work as an attorney for major traders. $\mathrm{He}$ was a judge, congressman, a ministry of the Empire, of War and Navy, a Senator, a State Counselor, and the Chairman of the first Board of Trade of Brazil. After occupying the afore mentioned positions, he acted as an influential player in several debates about legal and political matters, among which we chose three: the creation of the act of liability for ministries of State of 1827; the debates on the Criminal Code of the Empire, created in 1830, and of the Commercial Code of 1850. The debates show the challenges that were set for the establishment of the Brazilian State and Nation, in a context of transformation of the Law represented by the modern set of codification ideas and changes in politics, with the growing centralization of monarchical power, but also with its limitation, starting with the onset of constitutionalism.
\end{abstract}

Key-words: José Clemente Pereira - Creation of national law - Codification Criminal Code of the Empire - Commercial Code of the Empire - Constitution of the State - Constitucionalism 


\section{SUMÁRIO}

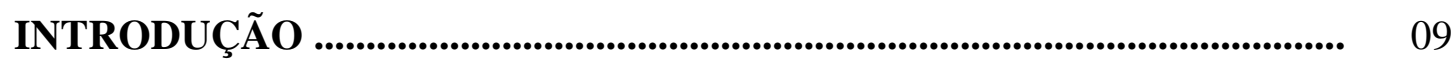

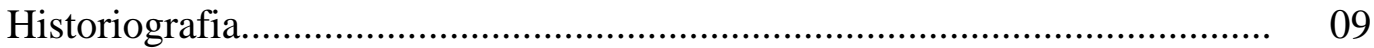

Estrutura do trabalho................................................................................. 22

1. CLEMENTE PEREIRA E O DEBATE JURÍDICO DO IMPÉRIO.......... 24

2.1 Independência............................................................................. 25

2.2 Vida política após o exilio: os processos de responsabilidade.................. 28

2. O CÓDIGO CRIMINAL_........................................................................ 51

3.1 Codificação penal no século XIX........................................................ 51

3.2 O código criminal no Brasil................................................................. 54

3.3 O projeto de Clemente Pereira............................................................... 63

3. O CÓDIGO COMERCIAL................................................................................. 70

4.1 O comércio no Brasil............................................................................ $\quad 70$

4.2 A criação do direito comercial nacional.................................................. 71

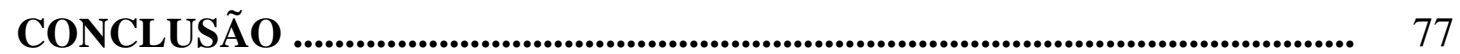

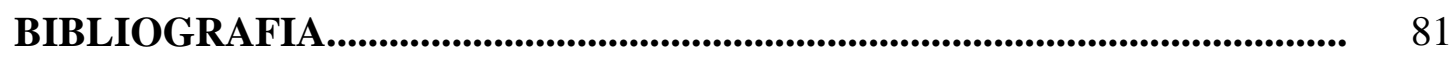

ANEXO 01 - Bases apresentadas por José Clemente Pereira em 1826 .............. 86

ANEXO 02 - Projeto de Código Criminal apresentado por José Clemente

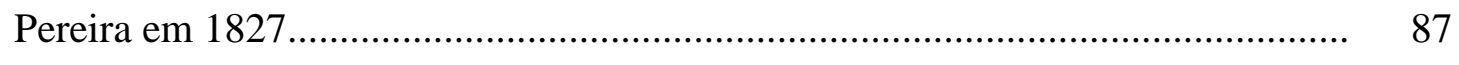

ANEXO 03 - Projeto de lei apresentado por Bernardo Pereira de Vasconcelos em 1827 


\section{INTRODUÇÃO}

O presente trabalho tem por objetivo analisar a participação de José Clemente Pereira, jurista e comerciante português emigrado para o Brasil, na elaboração de dois importantes marcos da atividade legislativa do Império após a independência: o Código Penal, aprovado em 1830, e o Código Comercial, aprovado em 1850. Em um contexto mais amplo a pesquisa visa contribuir para o estudo da formação de uma cultura jurídica propriamente nacional após a independência.

As décadas que se seguiram à separação entre Brasil e Portugal são um momento de construção de um estado liberal, burocrático e capaz de impor impessoalmente a lei. Os homens que se envolveram nessa tarefa viveram uma época de transição entre o antigo regime, colonial e não constitucional, em direção ao regime constitucional, com o Estado desempenhando diversas funções - que antes estavam a cargo de particulares - e dispondo de um aparato burocrático autônomo (Lopes, 2007b).

Eram "homens de ação antes que doutrinadores à moda da academia europeia", envolvidos na elaboração de um direito nacional, "o quanto possível autônomo do direito português e do direito colonial”, mas também na instituição desse estado constitucional e liberal. "Assim, a tarefa que na Europa era de reforma e modernização, no Brasil era quase de invenção. Ainda que, claro está, o novo direito brasileiro se visse na contingência de viver do velho direito colonial ou metropolitano" (Lopes, 2007b).

\section{Historiografia}

É nesse contexto que se insere nosso personagem. Nascido em 1787, em Portugal, emigrou para o Brasil em 1815. Foi deputado geral, deputado provincial, senador, Ministro do Império, da guerra e membro do Conselho de Estado. Participou direta ou indiretamente dos momentos mais significativos da produção jurídica no século XIX: a elaboração da Constituição de 1824, as reformas legislativas de 1828, a elaboração do Código Criminal de 1830, do Código de Processo Criminal de 1832, além de ter sido 
um dos protagonistas nos debates que antecederam a criação do Código Comercial durante boa parte do segundo quartel do século XIX.

Foi escolhido porque viveu este período como jurista e homem de interesses comerciais. Sua trajetória é significativa em diversos aspectos; entre eles, sua articulação entre o que poderíamos chamar de mundo português - era ligado aos portugueses que atuavam no comércio da Corte, representando jurídica e muitas vezes politicamente seus interesses, sendo chamado por Rodrigues (1975:40) de "líder da população portuguesa do Rio de Janeiro" - e o mundo brasileiro, podendo ser considerado membro da elite política do Império, tendo em vista que percorreu a trajetória típica dos integrantes deste grupo (Carvalho, 1996).

Vivenciou ativamente de momentos fundamentais da constituição de nosso Estado, participando da cena política principal ou dos bastidores junto aos homens que fundaram o Império - D. Pedro I, José Bonifácio de Andrada e Silva, Bernardo Pereira de Vasconcelos ${ }^{1}$, Evaristo Ferreira da Veiga ${ }^{2}$, Diogo Antônio Feijó ${ }^{3}$, mas ainda ativo entre a geração que o consolidou (1800 - 1833), como veremos (Mattos 2004, p. 138).

Como um dos pontos de partida para a pesquisa, foi investigada a produção historiográfica sobre Clemente Pereira e seu grupo. Sem o objetivo de esgotar a produção, mas expor o que de mais relevante foi encontrado para os fins da pesquisa, a seguir listo os autores que colocam Clemente Pereira como um dos protagonistas das lutas políticas e debates jurídicos de seu tempo.

\footnotetext{
${ }^{1}$ Nasceu em Ouro preto, em 1795, descendente de família de jurisconsultos. Formou-se em Coimbra em 1819 , tendo sido eleito deputado geral em 1824, exercendo o cargo de 1826 até 1837; foi senador de 1837 até 1850, ano de sua morte. Foi membro do Conselho de Estado de 1842 a 1850, ministro da Fazenda de 1831-1832, ministro da Justiça e do Império de 1837 a 1839, ministro do Império em 1840. Exerceu ainda cargos no governo mineiro e intensa atividade jornalística.

${ }_{2}^{2}$ Natural do Rio de Janeiro, viveu entre 1799 e 1837. Responsável pelo periódico "A Aurora Fluminense". Foi tradutor e poeta, deputado geral entre 1830-1836 pela província de Minas Gerais.

${ }^{3}$ Nasceu em São Paulo em 1787 e morreu em 1843. Foi padre, deputado junto às Cortes de Lisboa em 1821, deputado geral de 1826 a 1829 e de 1830 a 1833 e senador a partir de 1833. Foi Ministro da Justiça de 1831 a 1832, nomeado senador em 1833, eleito Regente do Império em 1835, cargo ao qual renunciou em 1837.
} 
Os escritos sobre ele se concentram nos acontecimentos dos anos de $1822 \mathrm{e}$ 1823, quando fazia parte do grupo liderado por Joaquim Gonçalves Ledo ${ }^{4}$ e que contava ainda com o Cônego Januário da Cunha Barbosa ${ }^{5}$. Nas obras que versam sobre a Independência do Brasil a referência a estes personagens é constante, e sua importância advém não só de sua atuação intensa naquele período, mas também da relação de antagonismo que desenvolveram com José Bonifácio de Andrada e Silva.

Em outros momentos da história em que ele ocupa cargos de destaque ou desenvolve atividades relevantes os registros historiográficos em geral não analisam suas ações, apenas as registram, diferentemente do que ocorre com os anos de 1822 a 1823, em que há análises mais voltadas para o sentido da atuação dele e de seu grupo, e do contexto em que se deram. Abordaremos a seguir alguns desses autores.

José da Silva Lisboa ${ }^{6}$ escreveu em 1827 a "História dos principais sucessos do Império do Brasil"; obra que se destaca não só pela importância do testemunho coevo, mas porque seus escritos vieram a constituir referência para aqueles que o sucederam. Pode ser considerada o marco inicial na construção da memória de D. Pedro I como herói dos acontecimentos de então, mas traduz de maneira obliterada a complexidade da luta política que se travava. Patrocinada pela Coroa, colaborou para a visão da independência como continuidade, mas destaca o surgimento da nação na separação de Portugal, processo conduzido pela autoridade consensual que D. Pedro representava (Bittencourt, 2006).

\footnotetext{
${ }^{4}$ Nasceu no Rio de Janeiro em 1781, filho de negociante abastado, tendo estudado humanidades e medicina em Portugal. Desde 1811 servia na contadoria do Arsenal do Exército e nela fez sua carreira burocrática até entrar na política em 1821; em 1833 exerce o cargo de deputado da Junta de Comércio. Era tido como líder do grupo e, junto com Januário da Cunha Barbosa, responsável pelo periódico Revérbero Constitucional Fluminense, que circulou entre 1821 e 1822, um dos mais importantes do período. Era proprietário de uma fazenda no distrito de Santo Antonio de Sá, mas residia na cidade, onde mantinha a loja de comércio que herdara de seu pai. Seu irmão, Custódio, fixara residência na cidade do Porto desde os fins do século XVIII, quando se formara em medicina na Universidade de Coimbra e se envolveu na Revolução do Porto (Rodrigues, 1975: 52 e ss. e Oliveira, 1999: 110 e ss.).

${ }^{5}$ Foi pregador da Real capela, conquistando em 1814 a propriedade da cadeira de filosofia racional e moral da Corte. Além de estar vinculado a proprietários de terras, mantinha relações com comerciantes atacadistas, pois parentes seus eram grandes negociantes estabelecidos no Rio de Janeiro desde fins do século XVIII (Oliveira, 1999: 110 e ss.). Foi o primeiro secretário do Instituto Histórico Geográfico Brasileiro e um de seus fundadores (Porto Alegre, 1991: p. 31).

${ }^{6}$ Viveu entre 1756 e 1835 . Em 1816 foi encarregado pela Coroa de redigir uma história da Corte do Brasil, que resultou na obra "Memória dos benefícios políticos do governo de El-rey D. João VI", publicada em 1818. Mais tarde, em 1826, foi incumbido pelo Imperador D. Pedro de elaborar uma história acerca da fundação do Império. Obteve o título de Visconde de Cairu.
} 
Ao longo do texto há referências extremamente negativas tanto ao absolutismo, quanto à democracia, chamada de "hidra da anarquia". O autor censura os homens que ao lutar contra o primeiro defendem a segunda, porque confundem "a conveniência de reformas necessárias de instituições defeituosas com a extravagância das inovações arbitrárias nas leis fundamentais da monarquia" (Lisboa, 1827, p. 02 da Parte X).

José da Silva Lisboa foi contemporâneo de Clemente Pereira, e com este rivalizou em diversos momentos. Lisboa era ligado a José Bonifácio, inimigo histórico dos maçons fluminenses, grupo do qual Clemente Pereira fazia parte. Um episódio revela, na obra, a oposição entre ambos. Em 23 de maio de 1822 Clemente Pereira, então presidente da Câmara da Cidade do Rio de Janeiro, promove vereação extraordinária perante $\mathrm{D}$. Pedro e profere discurso a favor da permanência deste no Brasil, pedindo a convocação de uma Assembleia Geral das Províncias do Brasil. D. Pedro, mesmo já ciente, a esta altura, da impossibilidade de se evitar a convocação da Constituinte responde de maneira dúbia: agradece a manifestação, mas declara que tão logo soubesse da vontade das demais províncias se manifestaria. Silva Lisboa ${ }^{7}$ se manifesta contra a ideia da convocação da Constituinte, recriminando o Presidente da Câmara, pois temia que se estivesse a dar motivos para as Cortes considerarem os brasileiros em rebelião ${ }^{8}$, perturbando assim a união entre os dois países ${ }^{9}$ :

No fervor da justa indignação dos patriotas [o grupo de Ledo] contra as Cortes de Lisboa publiquei a Reclamação XIV contra os

\footnotetext{
${ }^{7}$ Rodrigues se refere a ele como "retrógrado" e "chefe do pensamento de retaguarda" (1975: 43).

8 "A "revolução" era vista de maneiras diferentes. Pra alguns, significava a mudança nos rumos do processo de constituição do império luso-brasileiro, nos termos em que vinha sendo encaminhado pelo governo de d. João VI, cujas fronteiras a partir de então deveriam limitar-se ao continente americano, destacando-se a parte européia em função da política recolonizadora da Cortes portuguesas. Para outros, contudo, foi o meio através do qual o projeto do império luso-brasileiro, com o centro no Rio de Janeiro, poderia ser preservado - já que suspenso provisoriamente, seria reconduzido sob a liderança do imperador do Brasil e futuro rei de Portugal. Para Silva Lisboa, na obra em questão ["Memórias"], havia duas maneiras de se interpretar o termo revolução. Tratava-se, num primeiro momento, de evento a ser condenado, pois, na esteira da Revolução Francesa, provocava a destruição da ordem estabelecida, a inversão de princípios e a subversão de governos. Mas, a "revolução" que assinalou a separação de Portugal e a organização do Império, teria sido capitaneada por D. Pedro e estava, para o autor, revestida de positividade, posto que legitimada pelo herdeiro da Coroa e pelo governante legalmente instituído. Além disso, visava recompor as circunstancias que as "demagógicas" Cortes em Lisboa tentavam destruir". (Nagib, p.33).

${ }^{9}$ Lisboa, 1827 , p. 8. Ele recrimina fortemente o tom escolhido para a representação encaminhada ao príncipe regente em 20 de maio, que terminava com a seguinte frase: "já conheces, senhor, os bens e males que esperam a ti, e à tua posteridade. Queres ou não queres? Resolve-te, senhor”.
} 
opiniáticos, que instavam o senhor D. Pedro, então príncipe regente, para romper com Portugal, convocando uma assembleia geral de Deputados do Brasil na Corte do Rio de Janeiro (o que me atraiu tantas animosidades), desejando, de fosse possível, continuar a fazer parte da Grande Família da Nação Portuguesa, na conformidade das bases da Nova Constituição Política, fiz o manifesto do meu cordial voto esperar, que o Corpo legislativo nos fizesse a devida justiça. Porém foram vãs as minhas esperanças, pela contumácia e soberba dos arquitetos de ruína, causa da própria infelicidade e da presente separação entre Brasil e Portugal, por abalarem com soterrâneas cabalísticas uma monarquia de perto de oitocentos anos (Lisboa, 1827: 23, vol.1).

Em relação à convocação da Constituinte, cabe aqui mencionar a posição de José Bonifácio sobre a questão (Tarquínio, 1988), pois a resposta de D. Pedro à súplica pela permanência teria sido influenciada por ele. José Bonifácio se preocupava com a unidade do território e a ameaça do caos; nisso não diferia dos patriotas do Rio (expressão usada por Tarquínio para o grupo de Ledo), mas discordava deles da maneira e momento em que os acontecimentos deveriam se dar. No mais, a própria possibilidade de influência do Grupo sobre o monarca e sua ânsia em tomar parte nos acontecimentos desagradava José Bonifácio.

A obra de Visconde de Cairu reflete como a ideia de uma revolução e suas consequências eram temidas e negadas até as vésperas da Independência, e como o valor da monarquia e de seus titulares no Brasil deveria ser reconhecido e preservado. Assim, o grupo de Ledo, e Clemente Pereira por consequência, faria parte da "Cabala Maçônica e Jacobina", que flertavam com a anarquia e se utilizavam da demagogia, ainda que muitas vezes em sua obra essa menção não seja explicita.

João Armitage, em sua obra, “A História do Brasil”, de 1834, traz uma visão da independência diferente: a de uma revolução, que significou não só a separação política de Portugal, mas também um processo civilizatório, resultado da filosofia moderna. Trata-se de um fenômeno inevitável, resultado do confronto entre colônia e metrópole, e produto da coesão de grupos que, mesmo rivais, se uniram em torno de D. Pedro contra as Cortes. A monarquia, por sua vez, é vista como o caminho natural a ser 
seguido, porque mais adequado à introdução dos princípios do governo representativo elemento que autor valoriza. Processo civilizatório que é frustrado na abdicação de D. Pedro, resultado do conflito entre patriotas liberais e realistas (Oliveira, 1999). De maneira geral, suas descrições se dão em termos duais: colônia/metrópole, natos/portugueses, realistas/liberais, e os personagens são movidos por paixões ou ambições, e retratados como inexperientes. Refere-se aos membros do grupo liderado por Gonçalves Ledo e José Clemente Pereira como "liberais, partidaristas da independência", de tendência democrática e defensores da soberania da Assembleia Constituinte.

Manuel de Araújo Porto Alegre ${ }^{10}$, também contemporâneo de Clemente Pereira, traz alguns registros sobre em sua correspondência e em discurso feito no Instituto Histórico e Geográfico Brasileiro em 1854, ano da morte de Clemente Pereira. Refere-se a ele de maneira elogiosa, afirmando se tratar do "maior personagem da época e o homem da mais gigantesca biografia desta geração", com quem mantinha relações pessoais. Em um discurso proferido no Instituto Histórico e Geográfico Brasileiro, em 1854, Araújo Porto Alegre reconstitui a trajetória de Clemente Pereira ${ }^{11}$.

Na segunda metade do século XIX surge a historiografia que buscava fixar a separação como momento fundador de nossa história, dentro de um projeto de construção e consolidação da imagem da nação, movimento que teve como centro o Instituto Histórico Geográfico do Brasil, instituição fundada em 1838 e mantida pelo Imperador. Para estes autores, marcados pelos testemunhos de José da Silva Lisboa, “destacavam-se os aspectos políticos do movimento de separação de Portugal enquanto momento de advento da nação, sob a forma de uma monarquia constitucional promotora do progresso que se manifestava na unidade territorial e na defesa da civilização" (Bittencourt, 2006, p.38) ${ }^{12}$.

\footnotetext{
${ }^{10}$ Natural de São José do Rio Pardo, viveu entre 1806 e 1879, foi escritor, pintor, critico de arte e membro do Instituto Histórico e Geográfico Brasileiro. Exerceu o cargo de Cônsul geral do Brasil na Prússia e em Portugal, foi professor e diretor da Academia de Belas Artes e professor de arquitetura da Escola Militar.

${ }^{11}$ Revista do Instituto Histórico e Geográfico Brasileiro, t. XVII, Suplemento, 1854, p. 78.

${ }^{12}$ São estes autores responsáveis por um projeto consciente de nacionalização da escrita de uma história brasileira, que se valendo "de métodos pseudo-científicos que não obscureciam sua forte utilidade política e ideológica" colocaram no centro da questão duas ideias: a Independência como uma revolução positiva porque ordeira, e assentada na continuidade da dinastia de Bragança e na liderança pessoal de D. Pedro I (Pimenta, 2008: 68).
} 
João Manoel Pereira da Silva ${ }^{13}$, integrante do IHGB, escreve em 1865 a obra "História da Fundação do Império do Brasil". Sua análise se concentra nos grupos ligados ao Estado. Descreve D. Pedro como figura marcada pela ambiguidade, cuja força advinha da autoridade que assumiu de seu pai, D. João VI, este sim muito elogiado por Pereira da Silva. Mas apesar das dificuldades de atuação do regente, tudo se encaminha para um desfecho inevitável: a afirmação dos interesses dos homens à frente da administração que conseguem, através do príncipe, a manutenção das estruturas de governo no Rio de Janeiro. De acordo com ele,

José Clemente, Januário, Ledo, frei Sampaio, Curado, Nóbrega, Oliveira Álvares, barão de Santos Amaro e muitos outros brasileiros e portugueses, (....) na pessoa de D. Pedro depararam com o único elemento de salvação publica, e como príncipe, a quem no caso de lograrem a independência do Brasil, cabia de direito e por gratidão a Coroa americana (Pereira da Silva, 1865: 236 e ss, vol. 05).

Estes homens formam “o partido favorável à inteira independência do Brasil”. Sobre Clemente Pereira há uma nota interessante, que parece distingui-lo dos demais:

(...) preferia este, pelos seus sentimentos monarquistas, conservar-se o Brasil adeso à união, mas governado na ausência do rei pelo príncipe D. Pedro, com um centro próprio de administração suprema e instituições particulares. Quando se não pudesse lograr o ultimo alvitre, não trepidava ele em acompanhar os partidários decididos da independência, e abraçar o regime republicano, que outro se lhe afigurava então possível no caso de abandonar o Brasil toda a casa real de Bragança (Pereira da Silva, 1865: 86, vol. 05, grifo nosso).

\footnotetext{
13 Intelectual e político nascido no Rio de Janeiro em 1817, membro do Partido Conservador eleito deputado em 1844 e senador em 1887. Foi membro do Instituto Histórico e Geográfico Brasileiro, contemporâneo de Manuel de Araújo Porto Alegre, e um defensor engajado dos ideais de civilização, muito atuante no segundo reinado.
} 
Destaca-se ${ }^{14}$ dos demais por ser português, pelo seu papel de articulador, e os "sentimentos monarquistas" a ele atribuídos. Em diversos episódios Clemente Pereira aparece como aquele que faz a ligação entre seu grupo e o órgão que tomará as mais importantes iniciativas no curso dos acontecimentos: a Câmara do Rio de Janeiro. Esta articulação envolve, ainda, as lojas maçônicas, onde as discussões aconteciam e os planos eram traçados, onde se cobriam "os intentos, palavras e ações dos autores do movimento" e o corpo de Comércio do Rio de Janeiro, ao qual Clemente Pereira estava ligado, por suas atividades. Em outro trecho afirma que os que preferiam a independência ao regime republicano - entre eles Clemente Pereira

(...) passaram a adular e seduzir o príncipe, tendo concorrido para esta direção dos ânimos, e cuidaram desde logo a prestar forças ao regente, separando-o inteiramente da sujeição às cortes e do governo de Portugal, e aproveitando para o tornar inteiramente brasileiro (Pereira da Silva, 1865: 90, vol. 05).

À semelhança de outros autores aqui tratados, Pereira da Silva atribui papel decisivo ao grupo de Ledo, favoráveis à inteira independência do Brasil, para que aqui se constituísse um centro administrativo autônomo em relação a Portugal. Eram simpáticos ao regime republicano, mas tendo em vista seus objetivos, optaram pelo caminho que se mostrou viável: a monarquia constitucional conduzida pelo príncipe herdeiro.

Francisco Adolfo de Varnhagen ${ }^{15}$ vê a independência ${ }^{16}$ como processo salutar porque feito dentro da ordem e na continuidade da dinastia Bragança, com especial importância à figura de D. Pedro (Pimenta, 2008, p. 68). O processo de colonização e

\footnotetext{
${ }^{14}$ Os escritos de Pereira da Silva sobre Clemente Pereira são chamados por José Honório Rodrigues de "muito convencionais, louva-lhe tudo, a vida, a política, a administração, a obra de caridade, e chama-o de estadista, o último que restava daqueles que trabalharam pela independência".

${ }^{15}$ Viveu entre 1816 e 1878. Nasceu em Sorocaba, filho de engenheiro alemão que prestava serviços no Brasil. Ainda criança mudou-se para Portugal, retornando ao Brasil em 1840. Foi eleito sócio do Instituto Histórico e Geográfico permanecendo em Portugal como correspondente. Regressou ao Brasil em 1851 para assumir funções na diplomacia, e veio a ocupar o cargo de primeiro secretário do IHGB. Entre 1854 e 1857 publicou "História Geral do Brasil antes de sua separação e independência de Portugal". Contou com a proteção de D. Pedro II que em 1872, em reconhecimento aos seus méritos o fez Barão de Porto Seguro e dois anos mais tarde visconde.

${ }^{16}$ História Geral do Brasil (1854) e História da Independência do Brasil (1875).
} 
separação é visto como uma longa e necessária evolução ${ }^{17}$. Ao grupo maçônico, formado por José Clemente Pereira e Januário Cunha Barbosa, ele reserva as expressões "patriotas liberais" e "monarquistas constitucionais" (Neves, 1999, p. 31). Clemente Pereira foi, segundo ele, "um dos cidadãos que mais contribuiu para a proclamação da independência, e logo depois para o Império" (Rodrigues, 1975, p. 41).

Osvaldo Tarquínio de Souza $^{18}$ não foi propriamente historiador, mas contribuiu muito para o estudo do período pela pesquisa que dedicou à biografia dos principais personagens do período. Sua "História dos Fundadores do Império do Brasil" trata de D. Pedro I, José Bonifácio de Andrada e Silva, entre outros. O grupo de Ledo aparece muito, e a ele Tarquínio se refere como "os patriotas do Rio".

Tarquínio se preocupa em transmitir os conflitos em meio aos quais D. Pedro I se via e a complexidade do momento e de sua personalidade. De maneira geral transmite simpatia pela figura do monarca, sem deixar de ressaltar sua ambição como característica marcante e motor de seus atos. Em torno dele transitam as figuras que buscam influenciá-lo, entre eles José Bonifácio e os componentes do grupo de Ledo. No relato sobre as disputas entre eles Tarquínio também procura transmitir a riqueza das motivações e as características pessoais de cada um, mas ainda que se veja em conflito ideias e projetos diferentes, em relação especificamente ao embate Bonifácio "patriotas do Rio" parece prevalecer, acima de tudo, a busca pelo poder, pela ascendência sobre D. Pedro e pela autoria dos grandes lances.

As oportunidades para tal atuação surgem pelos dilemas que se apresentam ao regente. Dilema histórico, pois situado numa época de "guerras e revoluções, (...) ascensão da burguesia, movimento liberal, despertar de novas nacionalidades, tomada de consciência da América do seu lugar no mudo" (Souza, 1988a , p. 127 e ss.), "dilema dos reis, de dúvida entre conceder o estatuto constitucional ou recebê-lo imposto pela nação”. E também pessoal; D. Pedro, alienado pelo pai dos negócios da política, ansiava

17 Varnhagen desdobrou pressupostos interpretativos de Silva Lisboa preservando sua essência; polemizou com Pereira da Silva, mas não diverge dele em ver a figura de D. Pedro como o elemento de união de interesses (Bittencourt, 2006: 45)

${ }^{18}$ Nascido em 1889 em Pernambuco, formou-se em direito no Rio de Janeiro. Desenvolveu uma carreira burocrática, mas também se dedicou ao jornalismo, tendo escrito crítico literário e colaborado com grandes jornais. Sua obra histórica foi inaugurada em 1831 com "A mentalidade da Constituinte", tratando do período de 1823 a 1824. Seus escritos sobre os fundadores se iniciaram em 1937, com "Bernardo Pereira de Vasconcelos" e foram até "A vida de D. Pedro I" em 1952. 
por desempenhar seu papel na história. Divergia de D. João VI pai em caráter enquanto este se mostrava avesso a decisões, o jovem príncipe preferia o erro à postergação - e em ideias - D. João era "absolutista e não afeiçoado à monarquia constitucional, conservador no íntimo", enquanto D. Pedro não rechaçava o constitucionalismo, ainda que com a intenção de "ter parte nos sucessos e de associá-los à dinastia" (Souza, 1988a, p.164 e ss.), preferindo um constitucionalismo limitado, à semelhança de Luís XVIII, em que se viam "as franquias constitucionais como dádivas do monarca, e não como conquista da soberania nacional" ${ }^{19}$. Divide-se entre este horizonte político que não pode ignorar e a lealdade a sua dinastia e a própria manutenção do poder e estabilidade.

Importante mencionar estes elementos porque muitas vezes na disputa Bonifácio aparece como aquele que entende a situação de D. Pedro e, o grupo de Ledo, como aqueles que procuraram acelerar o desfecho dos acontecimentos. José Bonifácio é retratado como um homem "preocupado antes com a essência das coisas, com a realidade social" (Souza, 1988 a, p. 310 e ss.), "atento às condições sociais do Brasil, com sua carência de povo, e às circunstancias políticas do momento". O grupo de Ledo, por sua vez, "não participava do governo e avaliava mal as dificuldades que o enleavam, tendia a precipitar as questões e acumular problemas".

Nem tudo é ambição: se no grupo de Ledo havia "bajulação e o lado inferior da briga pela privança do príncipe e pela situação excepcional de José Bonifácio, existia também o ardor menos refletido, mas sincero, de partidários entusiastas da independência, que não continham a sofreguidão de atingir o mais cedo possível o objetivo final". Os patriotas são também corajosos (Souza, 1988b, p. 143 e ss.) e "empenhados sinceramente na causa da emancipação brasileira". Mesmo com suas “iniciativas imprudentes, com seu ardor combativo e proselitismo" foram responsáveis, por vezes, por trazer ao movimento "as mais profundas aspirações populares".

\footnotetext{
${ }^{19}$ Segundo Canotilho, "o significado político das cartas constitucionais, também chamadas "constituições outorgadas" resume-se em poucas palavras: continuar a monarquia sem manifestar declarada inimizade à idéia constitucional, relegitimar o poder constituinte monárquico sem rejeitar os novos esquemas de representação nacional, equilibrar o "Portugal velho" e o "Portugal novo" na titulariedade e exercício do domínio político. (...) "Outorgar" ou "dar" uma constituição significa a reafirmação da prioridade do monarca perante a nação - o poder constituinte monárquico existe antes do poder constituinte democrático. O rei contemporiza ou mostra clemência perante o "espírito constitucional" de seu tempo, mantendo o imaginário monárquico do passado" ("As constituições”, p. 154, apud Slemian, 2006a).
} 
Estas motivações pessoais prevalecem sobre as diferenças de projetos políticos quando havia divergência, mas o autor procura deixar bem claro que todos se valem da situação para obter suas próprias finalidades. Na articulação do Fico, por exemplo, declara terem seus promotores - entre os quais sabemos estar José Clemente agido "com prudência exemplar" (Souza, 1988a, p. 279): os "atos orquestrados são exemplo de admirável senso prático, inspirados por lucidez e objetividade", tendo tudo sido feito de maneira a "captar a adesão do príncipe e prendê-lo à causa do Brasil com um mínimo de constrangimento".

O medo da revolução, do republicanismo radical, do separatismo e do elemento popular não só colocava muitos grupos na mesma situação como colocava, para Tarquínio, o Brasil no mesmo contexto de outros países do mundo: "Todos estavam de acordo que o regime constitucional garantia a liberdade dos indivíduos e o direito de propriedade, e tinha a preferência de grupos que dominavam a economia na Europa e queriam resguardar o domínio político. À burguesia convinha a tranquilidade a assegurar as instituições liberais com autoridade estável, mas limitada. No Brasil, ainda que a situação não fosse idêntica, não faltava quem defendesse a monarquia constitucional, que ainda preservaria a unidade nacional”.

Mas não significa que os matizes da disputa entre diversos grupos não estejam presentes na obra - não só dos grupos entendidos como conjunto de indivíduos com um mesmo propósito intencional, mas enquanto classes com diferentes interesses, tais como proprietários rurais, comerciantes portugueses (que também ocupavam cargos na burocracia) e elementos urbanos. Não há muita riqueza na descrição dos objetivos de cada grupo, mas sua menção mostra a complexidade das disputas em questão. O uso da expressão "interesses econômicos" é pouco precisado ou explorado, de forma que não se pode ligar as divergências das ações aos interesses de seus promotores.

José Honório Rodrigues publicou "Independência: revolução e contrarevolução", em cinco volumes, em 1975. Bastante marcado por Armitage e Caio Prado, define a independência como revolução nacionalista que se delineia entre 1808 e 1831 . No quinto volume da obra, "A Liderança Nacional", o autor analisa a participação de diversos personagens do período, entre eles, José Clemente Pereira (Rodrigues, 1975, p. 41 e ss). 
$\mathrm{O}$ autor o caracteriza como ativo e enérgico, orador distinto de linguagem rude e contida, jurisconsulto talentoso e hábil. Mas era também contraditório, um "oportunista sem convicções" - oportunismo que permitiu que "fosse ele o único sobrevivente político da revolução da independência". Classifica-o como subserviente, covarde e servil, que "não inspirava confiança aos brasileiros, protegia os portugueses e flutuava constantemente de opinião". Mas isso não muda seu protagonismo na Independência, e pôde ele trazer para a causa "não só o seu nome, mas um partido poderoso e influente, os portugueses", interessados na manutenção dos privilégios criados com a vinda da Corte para o Brasil: liberdade comercial, tribunais superiores e as garantias individuais para os cidadãos.

Segundo Rodrigues não há erro maior em pensar que fosse republicano; era sim absolutista e ultraconservador, pois "adaptou-se inteiramente e serviu com dedicação ao absolutismo dominante e 1823 a 1831, quando D. Pedro fez o que quis". "Líder da população portuguesa, que foi aos poucos aceitando todos os ideais, desde as bases da constituição decretada pelas Cortes, até o da independência"; ele foi contraditório e sua atitude política foi "ora liberal, ora absolutista", pois se uniu ao grupo liberal mas continuava unido aos portugueses.

"Representando este grupo forte, pela importância econômica, dos grandes comerciantes e proprietários, influente pela massa de caixeiros que agitava as praças desde os primeiros movimentos, José Clemente Pereira concorreu para os passos decisivos no caminho para a independência”. Sua atuação permitia dar representatividade às ideias defendidas pelo grupo de Ledo, tendo em vista que as iniciativas eram sempre conduzidas a partir da Câmara do Rio de Janeiro, da qual era presidente.

Cecília Helena L. de Salles Oliveira (1999) investigou a fundo a atuação do grupo e seus conflitos com José Bonifácio, sustentando que as disputas da independência resultaram de imbricados interesses em luta num contexto de mudanças econômicas que já se esboçavam desde antes da transferência da Corte em 1808. Tratase do processo de mercantilização da terra e da mão-de-obra que acontecia não só no Rio de Janeiro como em algumas regiões de Minas Gerais e São Paulo, desde meados 
do século XVII. Com a reorganização econômica decorrente da decadência da extração do ouro, a terra passa a ser instrumento de obtenção de lucro, e a agricultura passa a ser uma das atividades mais lucrativas da região.

A vinda da família real inaugurará então um período de políticas econômicas contraditórias, em que a intervenção do governo foi a um só tempo protecionista, com o objetivo de manter os privilégios do monopólio comercial que beneficiava Portugal, e liberalizante, pois visando aumentar a produção propiciou o desenvolvimento de atividades econômicas independentes. Todo esse quadro se inseria num contexto mundial de gradual extinção das regulamentações do antigo regime e instauração de relações de livre mercado.

A autora desvenda as relações entre negócios e discurso político, mostrando a disputa entre grupos com diferentes interesses econômicos que surgem na arena política disputando poder e influência. Um destes grupos era composto pelos proprietários de duas regiões o Recôncavo da Guanabara e Campo de Goitacazes, na província do Rio de Janeiro, que produziam para exportação e abastecimento do mercado interno, mas se distinguiam dos tradicionais proprietários de grandes latifúndios e escravos, mas com eles disputavam negócios e poder.

Uma destas disputas se dava em torno dos contratos de arrematação de cobrança de impostos, negócio extremamente lucrativo por seu volume - houve um grande aumento na criação de impostos entre 1808 e 1821 - e modelo. O processo era controlado pelo Real Erário e Câmaras Municipais, privilegiando-se negociantes atacadistas, famílias poderosas e membros da alta burguesia. Contra isso se insurgiam os proprietários do Recôncavo e Goitacazes, pois não tinham acesso a esses privilégios.

Lucia Maria Bastos Pereira das Neves (2003) analisou a formação da cultura política luso-brasileira da Independência, seus atores, discurso e desdobramentos. Segundo ela, o liberalismo português tinha por característica ser bastante mitigado, sendo impregnado de tradicionalismo e incapaz de romper definitivamente com algumas barreiras do Antigo Regime. Esta foi a matriz do liberalismo brasileiro, que se apropriou do discurso do movimento constitucionalista de Portugal acontecido em 1820. 
O vintismo foi um movimento de reduzido fôlego, tanto por seu contexto - a Europa pós-revolução francesa dominada pela Santa Aliança - quanto por suas características próprias. Mas ainda assim introduziu práticas inéditas e representou, em certa medida, o advento da ideia de que a política era capaz de conduzir os destinos da sociedade, trazendo assim uma visão alternativa à liturgia, à visão de um mundo regido pela ordem tradicional. As mudanças podem ser sintetizadas na conversão da Coroa em Estado, na criação de uma esfera pública - ou opinião pública -, no incremento das instâncias de sociabilidade e no papel que a representação adquirirá.

Por outro lado, a religião não deixará de ter seu papel fundamental de conferir sentido à vida da maioria da população, desempenhando forte papel na manutenção de alguns limites do Antigo Regime. O monarca continuará a ser o centro aglutinador da vontade geral, não sendo superado pela soberania da nação. A imensa maioria da população continuará sem identidade e representação política, ainda que essa tenha sido ampliada de maneira significativa.

\section{Estrutura do trabalho}

O trabalho se divide em quatro capítulos. O primeiro deles, introdutório, coloca os objetivos e pontos de partida do trabalho. É nele também exporemos brevemente sua trajetória, situando-o no contexto de seu tempo, para que se possa entender melhor sua atuação no debate jurídico durante as décadas a serem abordadas: 1830 a 1850. Não se pretende com isso fazer uma biografia do personagem, mas articular elementos que nos permitam interpretar o sentido de sua trajetória, muitas vezes controversa. Por isso as informações sobre sua vida são selecionadas a partir de sua relevância para o objeto de sua investigação e, na medida do possível, dados secundários - sob esse ponto de vista serão mencionados em notas de rodapé.

No segundo capítulo trataremos da criação do Código Criminal do Império, do qual Clemente Pereira participou de maneira secundária, ao analisarmos a historiografia sobre o assunto. Esse caráter de coadjuvante será questionado pelo trabalho. Note-se que nessa parte da investigação será necessário retroceder alguns anos, pois o Código Criminal, aprovado em 1830, teve seus debates iniciados em 1826, primeiro ano de funcionamento do parlamento brasileiro, e quando o primeiro projeto para o Código foi 
apresentado - por Clemente Pereira, ou seja, um ano antes da iniciativa de Bernardo Pereira de Vasconcelos. O terceiro versará sobre a criação do Código Comercial, na qual, em compensação, é notório o protagonismo de nosso jurista. O diploma, aprovado em 1850, começa a ser engendrado em 1832, passa a tramitar no Senado em 1846, onde Clemente Pereira e Vasconcelos defenderão pontos de vistas opostos. No quarto capítulo colocaremos estes debates sob a perspectiva do contexto geral do ambiente jurídico da época, concluindo a pesquisa.

As principais questões que perpassam o tema, e às quais procuraremos responder são: (1) qual foi a participação de José Clemente Pereira na criação destes dois códigos? (2) de que maneira elas se articulam? (3) qual o sentido de suas ações, à luz de sua formação jurídica, interesses econômicos, classe social, ideias e projetos? (4) quais os projetos de poder em disputa? 


\section{CAPÍTULO 1}

\section{CLEMENTE PEREIRA E O DEBATE JURÍDICO DO IMPÉRIO}

José Clemente Pereira nasceu em 1786, na freguesia do Adem ${ }^{20}$, em Portugal. Estudou na Universidade de Coimbra já reformada por Pombal entre 1810 e 1815, tendo se formado em cânones ${ }^{21}$. De acordo com Neves (2003) essa formação imprimirá em uma geração - a elite coimbrã - um ideário reformista e pragmático, de um liberalismo atenuado, em oposição à "elite brasiliense", instruída na colônia, sensível muitas vezes ao republicanismo. Apesar das distinções, os dois grupos são parte da mesma cultura política, mas após a independência haverá radicalização (Oliveira, 1999).

Em 1815 emigrou para o Brasil e em 1818, poucos anos depois de sua chegada, tornou-se juiz de fora em Praia Grande ${ }^{22}$, onde possuía terras (Oliveira, 1999, p. 111), nas quais cultivava gêneros de abastecimento para o mercado local. Tomou posse do cargo em 1819 e foi o responsável pela criação da incipiente infraestrutura para o local, inclusive a construção de mercados, o que fez angariando recursos entre os proprietários da região (Carvalho, 2002, p. 44) - mas também com recursos próprios.

Outra forma de atuação política se dava com a participação em Irmandades, que reuniam muitos associados, propiciando, sob o manto das atividades de caridade, um ambiente de discussão politica e de negócios. Além disso, as próprias obras de caridade beneficiavam seus promotores, pois representavam "uma via de injunção entre as atividades públicas e privadas", pois os recursos que mantinham as instituições eram particulares. Por esse motivo o nome de Clemente pereira estará associado a algumas dessas instituições até hoje.

Essa faceta de Clemente Pereira é importante por mostrar a complexa teia de relações políticas, sociais e econômicas nas quais se inseria, ultrapassando os mais conhecidos meios de atuação como a maçonaria e os cargos na burocracia e mandatos

\footnotetext{
${ }^{20}$ Todas as informações biográficas são baseadas em Carvalho (2002), a não ser que haja indicação em sentido diverso.

${ }^{21}$ Durante este período integrou as chamadas tropas acadêmicas, como eram chamados os contingentes de estudantes que enfrentaram as tropas francesas durante a invasão napoleônica.

${ }^{22}$ Atualmente Niterói.
} 
eletivos. E é a partir dessa inserção na política local, o que parece já ser demonstração de suas habilidades de articulação política, é que toma parte nos acontecimentos conturbados que antecederam a independência do Brasil, entre 1821 e 1822.

De acordo com Tristão de Alencar Araripe, "sendo português, rico e magistrado, pôde trazer para o lado brasileiro a parte portuguesa, muito numerosa $\mathrm{e}$ economicamente poderosa, que aceitava não a independência, mas a manutenção dos privilégios que a autonomia, com o Reino, havia dado aos comerciantes, proprietários rurais e urbanos e escravagistas: o comércio livre, a justiça local, e muitas outras vantagens (apud Rodrigues, 1975, p. 49).

De acordo com o próprio José Honório Rodrigues, "tudo faz crer que ele persuadiu os portugueses, comerciantes e proprietários, que seria do interesse deles, senão a Independência, pelo menos a autonomia, com a liberdade comercial, os tribunais superiores, os privilégios do cidadão, tais quais existiam com o Reinado".

\subsection{A Independência do Brasil}

Em agosto de 1820 eclode a revolução do Porto em Portugal, que no esteio da crise econômica provocada pela invasão francesa e consequente saída da família real de Lisboa convoca Cortes para elaboração de uma nova constituição, cujo juramento será exigido de D. João VI em 1821. Manifestações de apoio surgem no território nacional, e José Clemente Pereira participa e lidera movimentos nesse sentido, que resultam no juramento do monarca às bases constitucionais em elaboração.

No mesmo ano Clemente Pereira é nomeado juiz de fora da cidade do Rio de Janeiro, o que pode ser entendido como indício de sua rápida ascensão. Será a partir de seu comando da Câmara que ele articulará a legitimação das intenções do grupo político que formará com Joaquim Gonçalves Ledo e o Cônego Januário da Cunha Barbosa.

Ledo e Januário desempenharão um importante papel nos deslindes e configuração da separação de Brasil e Portugal. Formam a "elite brasiliense, que concebia o poder como algo próximo à monarquia republicana de Sièyes", em oposição aos "governistas 
da elite coimbrã", formada pelos irmãos Andrada ${ }^{23}$, Severiano Maciel da Costa (Marquês de Queluz) $^{24}$, José Joaquim Carneiro de Campos (Marquês de Caravelas) ${ }^{25}$ e José da Silva Lisboa (Visconde de Cairu).

Constituíam duas propostas liberais, mas de diferentes origens e matizes. Os primeiros defendiam um modelo "mais centralizador do que federativo, mais monárquico que parlamentar e mais estatizante”. Na avaliação de Lynch (2005, p. 620), "dada sua maior proximidade da Coroa, o menor peso dos interesses particulares conferia-lhes maior sensibilidade quanto a temas estratégicos da construção do novo império". Eram "tributários do despotismo esclarecido, da retórica realista, centrada na autoridade monárquica como representante da soberania nacional (...) em que o político prevalecia sobre o econômico".

Já os brasilienses, "mais representativos dos interesses da lavoura (...), condenavam a interferência do Estado na economia por meio de um discurso liberal econômico que implicava na submissão do Estado [a esses interesses]". Independentemente de serem qualificados pejorativamente como democratas, republicanos e jacobinos por seus inimigos (e em resposta os qualificarem de absolutistas) e se utilizarem de uma retórica democratizante, defendiam a manutenção da escravidão em função dos interesses de seus membros, compostos por grandes senhores de terra e comerciantes portugueses. Pode-se dizer que aqui o econômico prevalecia sobre o politico.

Durante o ano de 1821 se desenha o seguinte cenário: a elaboração da Constituição em Lisboa, celebrada no Brasil, se torna palco de conflitos a partir do momento em que

\footnotetext{
${ }^{23}$ José Bonifácio de Andrada e Silva era irmão de Martim Francisco Ribeiro de Andrada e Antônio Carlos Ribeiro de Andrada Machado e Silva, todos naturais de Santos. O primeiro nasceu em 1775 e morreu em 1844. Participou do Governo Provisório da Província de São Paulo em 1821, foi Ministro da Fazenda entre 1822 e 1823 e em 1841, deputado constituinte e geral (1830-33 / 1836-1837 e 1838-41). O segundo viveu entre 1773 e 1845. Foi preso por ter sido acusado de participar da Revolução em Pernambuco em 1817; depois de solto foi eleito deputado representante de São Paulo para as Cortes de Lisboa, em 1821. Foi deputado constituinte em 1823 e deputado geral entre 1838 e 1841 . Foi ainda Ministro do Império de 1840- 1842.

${ }^{24}$ João Severiano Maciel da Costa, Marquês de Queluz, nasceu em Minas Gerais, viveu entre 1769 e 1833. Formado em Direito na Universidade de Coimbra, ouvidor da província, desembargador do Paço, ministro da Fazenda, do Império e Conselheiro de Estado, entre outros cargos. Foi ainda deputado geral e senador.

${ }^{25}$ Nascido em 1768, na Bahia, formou - se em Teologia e Direito pela Universidade de Coimbra. Voltou para o Brasil em 1807; em 1818 ingressou no conselho de D. João VI. Foi deputado pela província do Rio de Janeiro (suplente de Joaquim Gonçalves Ledo), Ministro em 1823, 1826 e 1829 e o primeiro regente provisório. Foi conselheiro de estado e faleceu em 1836.
} 
as atitudes dos deputados portugueses começam a ser interpretadas pelos brasileiros como opostas aos interesses do Brasil. Lembrando que até então, o fato de os homens de ambos os lados do Atlântico se virem como integrantes da mesma nação não obscurecia a visão de que o Brasil possuía suas especificidades.

O auge do conflito se dá com a retirada dos representantes brasileiros e a partir de então surge no discurso político a atribuição de intenções recolonizadoras aos portugueses. Não cabe aqui entrar em detalhes sobre esse período, limitando-nos a destacar que em pouco tempo esse conflito evoluirá para o questionamento da manutenção dos laços de união entre Brasil e Portugal.

Abre-se então uma brecha no sistema de poder, bastante fechado e centrado a figura de D. João VI, e vários grupos políticos, com projetos diversos, passam a ver nos acontecimentos uma oportunidade de exercício de um poder real. No centro da disputa estará D. Pedro, cuja ascendência esses homens passam a disputar arduamente. Como lenha nessa fogueira atuará a própria personalidade do príncipe e o papel que o herdeiro do trono passará a vislumbrar para si no desvelar dos acontecimentos.

Um desses grupos é o de Ledo - o jornalista ficará conhecido como o líder deles que Clemente Pereira integra. Por isso a importância da posição por este ocupada para a configuração da estratégia do grupo.

Em abril de 1821 D. João VI retorna a Portugal, deixando regente D. Pedro I. Os meses que transcorrerão entre este fato e a aclamação e D. Pedro Imperador do Brasil (outubro de 1822) serão o "momento fundamental de definição das forças que emergiram para instituir a monarquia constitucional (...), de intensa luta política, onde a liderança de D. Pedro e o projeto político que representava estava em debate, no seio da sociedade" (Bittencourt, 2006, p. 29) ${ }^{26}$.

Ao final de 1821, as Cortes determinam o imediato retorno de D. Pedro para Portugal. Clemente Pereira, como presidente da Câmara, participa ativamente das articulações que resultam na permanência de D. Pedro no Brasil, o conhecido episódio

\footnotetext{
${ }^{26}$ Estas lutas nãos e restringiram aos personagens que serão abordados nesse trabalho. Ver Bittencourt (2006) e Oliveira (1999).
} 
do Fico, em 09 de janeiro de 1822. A construção do "Fico" se deu a partir da aliança estratégica de diversos setores, sendo importante lembrar que é esse o momento fundante da monarquia constitucional no Brasil (Bittencourt, 2006 e Lynch, 2005).

A partir da decisão pela permanência de D. Pedro, em janeiro de 1822, o governo é reorganizado e José Bonifácio de Andrada se torna Ministro de Estado. Pode se identificar aqui claramente o momento em que vai se instaurar as relações conflituosas entre o grupo de Ledo e José Bonifácio, que possuíam projetos políticos diferentes, conforme já descrito. No conturbado período que vai desse início de 1822 até meados de 1823 esses dois núcleos disputarão a ascendência sobre D. Pedro e o protagonismo nos acontecimentos, com vitórias e derrotas para ambos, com consequências profundas para os desdobramentos políticos, mas de caráter efêmero para os personagens, tendo em vista a velocidade com que se alternarão entre o auge e o fundo do poço no poder.

Os acontecimentos que marcarão estas disputas serão a convocação de um conselho de procuradores de província, a convocação de uma assembleia constituinte no Brasil, o rompimento com as Cortes e o juramento prévio da Constituição a ser elaborada no Brasil. É nesse contexto que a oposição entre eles vai se agravando, até o momento em que José Bonifácio promove uma devassa contra seus inimigos, que sem julgamento são expulsos do Brasil. Entre eles, Clemente Pereira, que vai para a França em dezembro de 1822.

\subsection{Após o exílio: os processos de responsabilidade}

Mas o exílio não significou o fim de sua vida política, muito pelo contrário. Em pouco tempo são os Andradas que caem em desgraça; seus opositores são inocentados e Clemente Pereira volta ao Brasil em agosto de 1823. Já em 1824 é condecorado com títulos por D. Pedro e dois anos depois, em 1826, o encontramos eleito deputado pela Província do Rio de Janeiro para a primeira legislatura (1826 a 1830).

O crime de Clemente Pereira e de seu grupo teria sido o de querer para o Conselho de Províncias e, mais tarde, para a Assembleia Constituinte, mais poder do que o desejável na visão de José Bonifácio. A transformação dessa imputação em uma acusação de conspiração contra o poder do monarca não foi algo difícil de operar num 
momento de grande mudança política, em que havia tanto em jogo. De maneira geral, para os homens que viveram essa época, a questão da independência tinha muitos significados, não correspondendo, necessariamente, à separação total do governo de Portugal. O que parecia ser muito claro para estes homens que lutavam por tomar parte na condução dos destinos da nação era a oportunidade que se abria para o exercício do protagonismo na esfera da política e a defesa de seus interesses.

Mais tarde, em 1830, ele estará novamente sob acusação, mas dessa vez pelo crime contrário. Diante daqueles que lutavam pela limitação dos poderes do monarca, ele aparecerá como o grande apoiador dos resquícios de absolutismo. Esse ritmo constante de ascensão e queda não será exclusividade de Clemente Pereira; outros homens terão tal sorte, como o próprio José Bonifácio. Mas poucos - e talvez nenhum - a viverá com a intensidade e longevidade de nosso personagem: da devassa e exílio em 1823 até sua morte em 1850, passando por dois processos de responsabilidade como ministro, em 1829 e 1831, um processo de questionamento de sua elegibilidade em 1829 e muitos momentos de protagonismo ou significativa participação na vida política. Além de suas habilidades, esse ir e vir deve ser interpretado a partir do contexto político: o que estava em jogo, defendido por quem e com quais armas e estratégias.

Eleito então para a primeira legislatura, ele se torna um parlamentar bastante ativo. Além das duas iniciativas voltadas à elaboração do Código Criminal - que serão tratadas no próximo capítulo - apresentou, entre outros, projeto de abolição do tráfico negreiro prevendo sua extinção em $1840^{27}$ e de regulamentação da vigência das leis ${ }^{28}$, ambos de maio de 1826.

Participou das discussões de uma importante lei elaborada no período, a lei de responsabilidade dos ministros, de 15 de outubro de 1827, que regulamentou os artigos da Constituição sobre o tema. Os debates sobre a lei na Câmara vão de maio a outubro de 1826. Deles participaram ativamente Bernardo Pereira de Vasconcelos, um dos

\footnotetext{
${ }^{27}$ APB, 19 de maio de 1826.

${ }^{28} \mathrm{APB}, 11$ de maio de 1826.
} 
líderes da iniciativa, Lino Coutinho ${ }^{29}$, Vergueiro, Souza França ${ }^{30}$, Silva Maia ${ }^{31}$ e Clemente Pereira, entre outros.

As discussões se iniciam pela conveniência de se abarcar a responsabilidade de todos os empregados públicos, decidindo-se que a lei seria apenas para ministros e conselheiros, como queria Vasconcelos. Outros temas objeto de disputa foram as penas, o grau de detalhamento com que os crimes deveriam ser descritos, a responsabilização dos conselheiros de estado e a forma de processamento e acusação. Clemente Pereira opina em praticamente todos esses temas, oferecendo inclusive emendas em alguns pontos. De maneira geral, parece demonstrar uma maior preocupação com o rigor dos termos da lei em oposição a Vasconcelos, que defende fórmulas mais amplas. A lei foi aprovada na Câmara em agosto de $1826^{32}$ e enviada ao Senado.

A responsabilidade dos ministros era um dos pontos centrais do governo representativo trazido pela Constituição de 1824. Como se sabe, a carta instituíra o Poder Moderador ${ }^{33}$, reservando ao monarca algumas prerrogativas, como a de nomear e demitir livremente os ministros de estado, que compunham o Poder Executivo, por ele chefiado $^{34}$. Por outro lado, a carta também previa a responsabilidade dos ministros ${ }^{35} \mathrm{em}$ oposição à inviolabilidade do Imperador. É nos ministros de estado que a oposição ao governo concentrará seu fogo, como forma de afirmação do Legislativo perante o Poder Executivo e Moderador. Dos ministros, "pouco afeitos à oratória e ao sistema

\footnotetext{
${ }^{29}$ José Lino dos Santos Coutinho nasceu na Bahia e viveu entre 1784 e 1836. Formou-se em medicina pela Universidade de Coimbra, foi deputado junto às Cortes de Lisboa, deputado geral nas duas primeiras legislaturas e ministro do Império (1831/1832).

30 Manuel José de Sousa França (1780-1856). Foi deputado constituinte pela Província do Rio de Janeiro e deputado geral (de 1826 a 1829, de 1845 a 1847 e em 1848). Ocupou a Pasta da Justiça em 1831 e na Regência.

${ }^{31}$ José Antônio da Silva Maia (1789-1853) era natural do Porto, Portugal. Foi Procurador da Coroa e Conselheiro de Estado. Ocupou a cadeira de deputado por Minas Geras na Constituinte de 1823, e na Assembleia Geral por duas vezes: na $1^{\text {a }}$ legislatura (1826-29), e na $2^{\text {a }}$ durante o ano de 1830 . Nesse ano, foi nomeado ministro do Império. Posteriormente, seria ministro da Justiça e da Fazenda (1840), e novamente do Império (1843-44). Foi escolhido senador em 1843.

${ }_{32}^{32} \mathrm{APB}, 03$ de agosto de 1826 , p. 17.

${ }^{33}$ Capítulo I do Título $5^{\circ}$, art. 98 e ss.

${ }^{34}$ A inspiração para tal modelo teria vindo da França, em oposição á experiência parlamentar inglesa (Dolhnikoff, 2008 e Lynch, 2005).

${ }^{35}$ Capitulo VI do Titulo $5^{\circ}$ (Do Ministério): “Art. 133. Os Ministros de Estado serão responsáveis: I. Por traição; II. Por peita, suborno, ou concussão; III. Por abuso do Poder; IV. Pela falta de observância da Lei; V. Pelo que obrarem contra a Liberdade, segurança, ou propriedade dos Cidadãos; VI. Por qualquer dissipação dos bens públicos; Art. 134. Uma Lei particular especificará a natureza destes delictos, e a maneira de proceder contra eles; Art. 135. Não salva aos Ministros da responsabilidade a ordem do Imperador vocal, ou por escripto".
} 
parlamentar de governo", demandarão "a obrigatoriedade de discutirem na Câmara as leis fundamentais, como a de fixação de forças militares e de aprovação do orçamento; de prestar contas de seus atos e serem por eles responsáveis, de apresentar relatórios, de atender a convocações" (Carvalho, 1999, p. 17). Vasconcelos expressa em diversos discursos sua revolta contra a atitude dos ministros.

Lynch (2005, p. 639) informa que "todas as constituições do século XIX, inclusive as ibéricas, designavam o rei como titular do Executivo”. Para Benjamin Constant (inspirador da teoria do Poder Moderador), "o fato de atribuir constitucionalmente ao monarca o exercício do Poder Executivo (...) não consistia em nenhum óbice ao funcionamento de sua teoria, desde que os negócios ordinários da administração ficassem, na prática, por conta de um ministério responsável", como de fato se previu na Constituição de 1824.

Assim sendo, o sistema baseado na inviolabilidade do monarca, de um lado, e a responsabilidade dos ministros, de outro, visava resguardar o preceito de que "o rei reina, e não governa". A questão política do Poder Moderador residia no fato de que, "ao distinguir a autoridade inviolável (o rei) de autoridade responsável (ministério), uma das finalidades perseguidas pela doutrina liberal [de Constant] era a de afastar o príncipe do exercício direto da atividade governamental”.

Mas a forma com que foi construído o "maquinário institucional" da monarquia permitiu que o rei governasse de fato, "sem que seus adversários pudessem recriminá-lo pelos desmandos decorrentes de seus atos, já que no melhor estilo das fícções constitucionais britânicas, dado o seu caráter inviolado e sagrado (art. 99), todas as culpas deveriam recair sobre seus ministros responsáveis".

Essa construção, na qual se arvorava o projeto centralizador da elite coimbrã conforme já descrito, se baseava "na interpretação do art. 102, segundo o qual o imperador era chefe do Poder Executivo, exercendo-o por meio de seus ministros, e do art. $101 \mathrm{VI}$, que permitia ao príncipe, titular do poder moderador, livremente nomear e demitir ministros sem interferência das câmaras". 
Foi isso que D. Pedro fez ao longo do seu reinado, e foi com o instituto da responsabilidade dos ministros - como configurado na lei de 15 de outubro de 1827 que os parlamentares combateram (ou tentaram combater) tais desmandos. Um dos pivôs desse conflito foi José Clemente Pereira, que por três ocasiões, uma vez de maneira indireta e duas vezes de maneira direta, se viu acusado com base na lei de responsabilidade. Nas três ocasiões restou salvo, não se podendo dizer que fosse exatamente inocente ou tenha saído incólume.

Em $1828^{36}$ tornou-se Ministro do Império, cargo que exerceu nos dois anos seguintes e cumulou, ao final de sua administração, com a pasta da Guerra. Por suas atitudes - ou omissões - praticadas enquanto ocupante de tais cargos é que foi acusado de crimes, como relataremos a seguir.

Na primeira vez, em 1829, o alvo foram os ministros da Justiça, Lúcio Soares Teixeira de Gouveia ${ }^{37}$, e da Guerra, Joaquim Oliveira Álvares ${ }^{38}$. Entre maio e julho daquele ano a Câmara discutiu se seriam inconstitucionais duas medidas conjuntas destinadas à Província de Pernambuco, cuja responsabilidade seria de tais ministros: a suspensão das garantias individuais por meio de um decreto e a criação de comissões militares, respectivamente. José Clemente Pereira era então o Ministro do Império, tanto à época das medidas quanto da acusação. Por um lado, sua posição de liderança no Ministério responsável pelas medidas faz com que os deputados o incluam nas censuras aos atos do governo; por outro lado, percebe-se certa reticência em acusá-lo diretamente, provavelmente pelo fato de que ele, estando no poder, ele concentrava poder em suas mãos.

A primeira análise, relativa à denúncia, é apresentada pela Comissão de Constituição em parecer lido na sessão de 29 de maio ${ }^{39}$, concluindo pelo cabimento em relação ao ministro da guerra, mas não ao ministro da Justiça. Vasconcelos e outros deputados se insurgem com a não inclusão de Lucio Soares, e se candidata para a comissão especial designada para analisar o assunto. O parecer dessa comissão é

\footnotetext{
${ }^{36}$ Ainda em 1826 é nomeado Desembargador da Relação da Bahia, cargo que não exerceu, e em 1827, intendente geral de polícia.

${ }^{37}$ Ministro entre novembro de 1828 a dezembro de 1829.

${ }^{38}$ Ministro da Guerra de janeiro a junho de 1822 .

${ }^{39}$ APB, 29 de maio, p. 167.
} 
apresentado em 02 de junho, e julgam pela procedência da denúncia em relação aos dois ministros. Os deputados então discutem se a segunda comissão poderia ter procedido dessa forma, acusando-os de terem extrapolados os termos que lhes foram submetidos, pois o primeiro juízo de admissão da denuncia excluíra o ministro da Justiça.

As críticas específicas a Clemente Pereira se tornam mais contundentes ao longo das sessões, principalmente porque ele defende o decreto de suspensão das garantias individuais ${ }^{40}$, afirmando que à época "a pátria se achava em perigo iminente", em razão da existência de rebelião visando "instalar o governo republicano", o que autorizava o executivo a decretar "a segurança do estado", dentro dos ditames da Constituição do Império $^{41}$. Em sua fala e nas que se seguem os deputados discutirão se houve rebelião em Pernambuco, ou se o movimento se tratou de simples sedição ou assuada ${ }^{42}$. Em 16 de julho defendeu, de forma ainda mais contundente, a criação das comissões ${ }^{43}$.

O primeiro esforço não foi bem sucedido: na mesma sessão, em 12 de junho, a Câmara decide pela procedência da denúncia ${ }^{44}$, nos termos do parecer da comissão de constituição, e desconsiderando a inclusão que a comissão especial pretendera. Ou seja, o ministro da Justiça, Lucio Soares, é considerado inocente. Seguiu-se então ciência ao denunciado e concessão de prazo para resposta, que foi apresentada em 20 de junho ${ }^{45}$.

\footnotetext{
${ }^{40}$ APB, 12 de junho, p. 85. Além disso, a Câmara solicitara ao Conselho de Estado a ata da sessão na qual a criação das comissões fora discutida. Vasconcelos afirma saber que o Conselho de Estado se posicionou contra tal expediente, mas a ata nunca chega ao conhecimento dos deputados. Clemente Pereira será visto como o responsável pela ocultação de tal documento.

41 “Art. 179. A inviolabilidade dos Direitos Civis, e Polticos dos Cidadãos Brazileiros, que tem por base a liberdade, a segurança individual, e a propriedade, é garantida pela Constituição do Imperio, pela maneira seguinte: (...)XXXV. Nos casos de rebellião, ou invasão de inimigos, pedindo a segurança do Estado, que se dispensem por tempo determinado algumas das formalidades, que garantem a liberdede individual, poder-se-ha fazer por acto especial do Poder Legislativo. Não se achando porém a esse tempo reunida a Assembléa, e correndo a Patria perigo imminente, poderá o Governo exercer esta mesma providencia, como medida provisoria, e indispensavel, suspendendo-a immediatamente que cesse a necessidade urgente, que a motivou; devendo num, e outro caso remetter á Assembléa, logo que reunida fôr, uma relação motivada das prisões, e d'outras medidas de prevenção tomadas; e quaesquer Autoridades, que tiverem mandado proceder a ellas, serão responsaveis pelos abusos, que tiverem praticado a esse respeito" (grifos meus).

${ }^{42} \mathrm{O}$ próprio Clemente Pereira comenta a confusão entre os termos, que não estavam claros na legislação. Para detalhes sobre o uso desses termos e sua previsão legal ver Dantas (no prelo).

${ }^{43}$ APB, 16 de julho, p. 126.

${ }^{44}$ A lei de responsabilidade, de 15 de outubro de 1827, estabelecia que após a denúncia (que podia ser feita por um cidadão, pelas comissões da Câmara e seus membro) uma comissão analisaria o assunto e caso não o rejeitasse, mandaria produzir provas e inquirir testemunhas. Se a denuncia fosse julgada procedente ela seria remetida ao acusado e, após a análise de sua resposta, esta mesma comissão ou outra concluiriam sobre o cabimento ou não de uma acusação, fornecendo seu parecer. Este parecer seria discutido em duas sessões para então ser votado.
}

${ }^{45}$ APB, 20 de junho, p. 143. 
O assunto então foi submetido a uma nova comissão, responsável por concluir se haveria ou não acusação, que apresentou seu parecer em 01 de julho ${ }^{46}$, afirmando que a criação de comissões não estava proibida pela constituição, não tendo o ministro incorrido em crime de responsabilidade ${ }^{47}$.

O documento é discutido calorosamente nas sessões seguintes, de 06 a 18 de julho. Muitos deputados usam da palavra para atacar o parecer, e poucos para defendê-lo; entre os últimos estão Miguel Calmon Du Pin e Almeida ${ }^{48}$, então Ministro da Fazenda ${ }^{49}$, Ledo $^{50}$, além do próprio Clemente Pereira ${ }^{51}$. O auge das discussões se dá no dia 18 , quando ao atacar o parecer, Ferreira França ${ }^{52}$ em sua fala chega a sugerir que se poderia duvidar da constitucionalidade do próprio imperador ${ }^{53}$. As falas a seguir mostram o desconforto que passa a pairar entre os Parlamentares e é bem confusa a interação entre eles, o presidente e as galerias. Parte dos deputados se apressa em defender o público; parte deles faz questão de afirmar que não estão agindo sob coação e outros, que o Parlamento respeita a pessoa do Imperador e nunca faltou com respeito. Alguns querem o adiamento da votação, exatamente pelo clima agitado, mas a proposta é vencida e a votação acontece, com aprovação do parecer por uma diferença de sete votos (trinta e nove a trinta e dois). ${ }^{54}$

Tobias Monteiro (1982, p. 68) afirma que o desfecho favorável foi resultado do esforço do Imperador em proteger seu ministro, e consequentemente, seus próprios

\footnotetext{
${ }^{46}$ APB, 01 de julho, p. 08. O grupo era composto pelos deputados Luiz Paulo de Araújo Bastos, João de Medeiro Gomes e José da Cruz Ferreira.

${ }^{47}$ Idem, p. 11. Importante notar que um dos membros, José da Cruz Ferreira, apresentou longo voto em separado, com argumentação diversa do parecer e muito amis contundente em reprovar o ministro, mas concluindo da mesma forma: não havendo lugar para acusação, uma vez que "não haja lei expressa, nem anterior, que proíba as comissões militares, porem uma dedução que não basta para constituir criminalidade em direito, e sem lei não haja crime nem criminoso".

${ }^{48}$ Miguel Calmon du Pin e Almeida, Marquês de Abrantes, Natural de Salvador, viveu entre 1796 e 1865. Formado em direito, ocupou diversos cargos, entre eles o de embaixador, de Ministro da Fazenda e do Estrangeiro, Conselheiro de Estado, deputado constituinte, geral por três legislaturas e senador a partir de 1840.

${ }^{49}$ APB, 17 de julho, p. 139.

${ }^{50}$ APB, 16 de julho, p. 128.

${ }^{51}$ APB, 16 de julho, p. 126.

${ }^{52}$ APB, 18 de julho, p. 148.

${ }^{53} \mathrm{O}$ deputado nem consegue terminar a frase, e grande agitação se dá, tanto entre seus colegas como nas galerias, que são chamadas à ordem pelo presidente e até mesmo pelo ministro da justiça, que brada "A pessoa do imperador é inviolável!".

${ }^{54}$ A ata do dia 18 de julho traz a lista completa dos deputados que votaram contra e a favor (p. 161).
} 
interesses: o conhecimento do conteúdo da ata do Conselho de Estado teria revelado que o monarca agira por si, o que lhe imporia um alto custo político, mas não anularia a responsabilização do ministro, uma vez que a Constituição determinava que os ministros eram responsáveis pelos atos elencados no art. 133 independente de ordem do Imperador, verbal ou escrita (art. 135).

O autor descreve a estratégia de D. Pedro para influenciar o resultado dos debates ${ }^{55}$, mencionando inclusive, que entre os votantes estavam os ministros em exercício. De fato, alguns deputados se insurgiram contra a possibilidade de esses ministros votarem. Entre eles, Clemente Pereira e Calmon, que defende os atos do ministério ${ }^{56}$. Outra forma de pressionar os deputados teria sido a ocupação das galerias por militares durante a votação, como forma de pressioná-los. Como relatamos acima, as atas das sessões dos dias 16, 17 e 18 de julho refletem a agitação do ambiente, mas não fica bem claro que os deputados se sentem constrangidos ${ }^{57}$. A reprovação desse ambiente e a ligação dessa ocupação com os interesses do governo só ficará clara nas falas dos deputados em 1830, que a atribuirão a Clemente Pereira; mas Monteiro afirma ter sido obra direta de D. Pedro.

Ao final do processo, porém, Oliveira Álvares é demitido da pasta da Guerra. Clemente Pereira a assume em agosto, sendo, por sua vez, demitido em dezembro de 1829 e sucedido por Tomás Joaquim Pereira Valente, Conde do Rio Pardo ${ }^{58}$.

Nesse ínterim, porém, Clemente Pereira fora reeleito deputado pela Província do Rio de Janeiro. Iniciar-se-á então o segundo capítulo da luta travada em 1829: os liberais, mais uma vez capitaneados por Vasconcelos ${ }^{59}$, tentam impedir que Clemente

\footnotetext{
${ }^{55} \mathrm{O}$ imperador teria, ainda, conclamado seus aliados para defender suas posições; entre eles Romualdo Antônio de Seixas, arcebispo da Bahia e mais tarde Marquês de Santa Cruz. Viveu entre 1787-1860, nascido no Pará. Sacerdote, foi presidente da Junta Provisória do Pará (1821-3).Foi deputado geral nas $1^{\text {a }}$ e $4^{\mathrm{a}}$ legislaturas (1826-9 e 1838-41) representando o Pará, e nas $3^{\mathrm{a}}$ e $5^{\mathrm{a}}$ (1834-7 e 1842-5) pela Bahia.

${ }^{56}$ Monteiro (1982, p. 168) destaca a rivalidade entre ambos, em especial nesse período, afirmando que o ministério se dividia entre "clementistas" e "calmonistas", tendo Calmon se aliado, alguns meses depois, a Bonifácio, inclusive. Mas é de se notar a posição aqui compartilhada entre ambos, que certamente se uniam na defesa do governo que integravam. Calmon agirá da mesma forma em 1830, como veremos.

${ }^{57} \mathrm{O}$ próprio testemunho de Feijó é contraditório em dois momentos: no próprio dia 18 de julho é um dos deputados a pedir o adiamento da votação (APB, 18 de julho, p. 150); um ano depois, em 02 de junho de 1830 (p. 300) defende Clemente Pereira diante dos deputados que o acusam de tal coação.

58 Tomás Joaquim Pereira Valente (1790-1849), Conde do Rio Pardo, foi Ministro da Guerra entre dezembro de 1829 e março de 1831.

${ }^{59}$ Custódio Dias, Bernardo Pereira de Vasconcelos, Luiz Cavalcanti, Ernesto Ferreira França.
} 
Pereira tome posse ${ }^{60}$, acusando-o de ser "suspeito à causa do Brasil" e de "professar o absolutismo", com base na sua atuação como Ministro do Império.

Os fatos eram basicamente os mesmos: a criação das comissões militares, mas era nova a roupagem acusatória com a qual a vestiam. A acusação se baseava no artigo $2^{\circ}, \S$ 7, das Instruções de 26 de março de 1824, a exigir que o eleitor (e por consequência, o eleito) fosse "homem probo, e honrado, de bom entendimento, e sem nenhuma sombra de suspeita e inimizade à causa do Brasil" ${ }^{61}$. A discussão então se organizará menos em razão da defesa de Clemente Pereira como ministro e mais em torno da interpretação a ser dada ao texto das instruções.

Isso porque parte dos deputados defendiam que essa interpretação era prejudicial ao próprio Parlamento e desrespeitava a soberania da vontade dos eleitores, conforme explicita Feijó em sua fala de 29 de maio ${ }^{62}$. Esses se insurgirão contra a exclusão de Clemente Pereira mesmo expressando reprovação a ele enquanto ministro. Esse grupo e a própria defesa elaborada pelo acusado - argumentava que a previsão das Instruções era um preceito, um conselho aos eleitores, não se podendo impedir o exercício do mandato por uma "suspeita". Essa era a chamada "questão de direito". O termo "suspeito" era a chave para a segunda parte do raciocínio, chamada de "questão de fato": não havia prova de que Clemente Pereira atentasse contra a constituição - e tivesse, portanto, cometido crimes. Estarão desse lado Feijó e José Martiniano de Alencar $^{63}$ (cuja atuação será chave, tendo em vista terem sido eles os autores do parecer favorável ao acusado), Paula Souza ${ }^{64}$ e Evaristo da Veiga ${ }^{65}$.

\footnotetext{
${ }^{60}$ Joaquim de Oliveira Álvares, eleito pela Província do Rio Grande do Sul, será novamente acusado, nos mesmos termos de Clemente Pereira.

61 “(...) a exigência de que o eleitor paroquial deveria ser um cidadão "sem nenhuma sombra de suspeita á causa do Brasil" propiciava a prática de todas as formas possíveis de discriminação por parte das autoridades responsáveis pela apuração dos votos nas assembleias primárias. A frase poderia receber múltiplas e contraditórias significações, dadas as circunstâncias que permeavam as relações de mercado e coerções, pressões e fraudes seriam legítimas, qualquer que fosse a conotação atribuída pelas Juntas Eleitorais à "causa do Brasil”" (Oliveira, 1999, p. 262).

${ }_{62}$ APB, 29 de maio, p. 269.

${ }^{63}$ José Martiniano de Alencar, nascido no Ceará, viveu entre 1794 e 1860. Foi ordenado sacerdote no seminário de Olinda, foi jornalista e ocupou diversos cargos, entre eles os de: Ministro da Justiça, presidente de província, deputado junto às Cortes de Lisboa, deputado constituinte, deputado geral e senador desde 1832. O escritor e advogado José de Alencar era um de seus filhos.

64 Francisco de Paula Souza e Mello nasceu em 1791 em Itu, São Paulo. Foi ministro do Império e da Fazenda, Conselheiro de Estado, deputado constituinte, deputado geral e senador desde 1833.

65 Monteiro afirma que foi ele quem articulou a posição favorável a JCP: "opôs-se à violência dos correligionários, mesmo tendo combatido [José Clemente] e detestá-lo. (...) Com espanto geral, mudou a corrente contrária, desviando para seu lado Feijó, Alencar, Paula Sousa, Ledo, elementos igualmente
} 
Seus acusadores, por outro lado, não se conformavam com tal interpretação. Além de argumentarem que nãos e tratava apenas de suspeita, mas sim de atos concretos do mandatário que provavam ser ele contrário à causa do Brasil e partidário do absolutismo, sustentavam que o dispositivo em questão não era conselho e sim comando, constituindo-se em elemento da elegibilidade do deputado, a ser conferida pela própria Câmara. Há, também, muita controvérsia sobre o procedimento a ser adotado, se semelhante ao instituído pela lei para a responsabilização de ministros ou não.

O ex-ministro era acusado de ter embaraçado a aprovação do orçamento de 1829, ter promovido ativamente a proteção de grupos que tramavam a volta do absolutismo (os deputados se referem a eles como "colunas" ou "japoneses"), de ter legislado usurpando poderes do Parlamento e criado cargos e favorecido indevidamente seus aliados - diga-se de passagem, portugueses. Mas afinal, qual era o cerne da questão? Diante de tantas acusações, o que estava realmente em jogo? Qual teria sido o verdadeiro ou principal crime do acusado, no julgamento de seus perseguidores?

As posições tomadas, argumentações desenvolvidas e juízos emitidos se articulavam em torno da oposição ser (ou agir como) absolutista e o ser (ou agir como) constitucional. Pois nada há de novo nessa afirmação: era esse o pano de fundo de todo o discurso político de então. Ir além dessa questão básica e afirmar qual era o cerne da perseguição a Clemente Pereira é caminhar em terreno frágil. Retomaremos a questão ao final do trabalho, quando concluirmos sobre o sentido de sua atuação politica e jurídica, mas apontamos alguns elementos que parecem relevantes para seguir a investigação desse episódio: todas as acusações feitas podem ser consideradas relevantes porque ligadas a pontos de disputa entre os dois centros de poder: a Câmara baixa e a Coroa.

Já nas sessões preparatórias, em abril, Custódio Dias e Vasconcelos levantam o impedimento de Clemente Pereira ${ }^{66}$. Ele está presente na sessão e afirma que fará sua

poderosos (...) Exortava os colegas a agirem como juízes e não vingadores e afirmava a vontade dos eleitores" (1982, p. 189).

${ }^{66}$ Falaremos de impedimento, mas o termo usado pelos deputados é a "validade de seu diploma". 
defesa no momento oportuno, mas pede ao presidente que a Câmara solicite ao governo os documentos ministeriais relativos ao período que ocupou o cargo; em resposta Custódio Dias já exorta os deputados a julgar sem esperar tais documentos, pois os “crimes ministeriais são muito difíceis de se provar", louvando o exemplo da Inglaterra, "que dispensa em certos casos essas formalidades que se exigem para os ordinários".

Mas os deputados decidem adiar a questão e esperar tais documentos. Em 01 de maio prestam juramento e Clemente Pereira não os acompanha (a partir de então só voltará a participar das sessões no início de junho, quando toma posse). Chegam os documentos solicitados ao governo, que são remetidos à comissão de poderes, que no dia seguinte já apresenta seu parecer ${ }^{67}$. Segundo o documento, "bem previa a Comissão que o Ministro, a quem nunca faltou a ousadia para repetidas vezes ferir a Constituição do Império, e talvez de todo aniquilá-la, teria também tido a prevenção de ocultar tudo o quanto pensasse lhe fora prejudicial". Concluem que não há documento que obste o reconhecimento da condição de deputado a JCP, motivo pelo qual recomenda que ele tome assento ${ }^{68}$. Muitos deputados não se conformam com o parecer e passam a discutir os documentos, que a comissão já tinha analisado.

Nos próximos dias a discussão muda um pouco de foco, mas continua centrada nos ataques ao ministério comandado por Clemente Pereira. Isso porque em 03 de maio acontece a sessão de abertura da legislatura, com a presença do Imperador, que profere a Fala do Trono. Nas sessões seguintes - de 06 a 13 de maio - os debates parlamentares serão dominados pela elaboração da resposta à Fala, e os deputados decidem encaminhar ao Imperador, junto com tal documento, uma congratulação pela demissão do ministério comandado por Clemente Pereira ${ }^{69}$.

Nesses debates versarão longamente sobre os atos desse ministério, e as acusações se multiplicam, partindo de vários deputados: Vasconcelos, Lino Coutinho, Martim

\footnotetext{
${ }^{67}$ APB, 02 de maio, p. 60.

${ }^{68}$ O parecer é assinado por Moniz Barreto, Luiz Cavalcanti, Augusto Xavier de Carvalho, José Bento Ferreira Leite e Ernesto Ferreira França, sendo este último voto vencido.

${ }^{69}$ As congratulações não incluirão o ministro da Justiça, excluído por inciativa de Holanda de Cavalcanti. Tal decisão não se dá sem oposição de alguns deputados, os mesmos que em 1829 tinham sido contra a exclusão de tal ministro do juízo de culpa pelas medidas relativas a Pernambuco.
} 
Francisco, Paula Souza, Holanda Cavalcanti ${ }^{70}$ e Limpo de Abreu ${ }^{71}$. Apenas Calmon defende a presunção de inocência dos acusados. Cabe notar que uma das acusações feitas a Clemente Pereira poderia muito bem ser imputada a Calmon, ao menos a ele estendida: a falta de orçamento em 1829, pois ele era então ministro da fazenda.

$\mathrm{O}$ auge do debate acontece em 14 de maio ${ }^{72}$, quando volta à ordem do dia $\mathrm{o}$ diploma dos ex-ministros. Aqui aparece de forma mais nítida as diferentes visões sobre a forma como se deveriam proceder em relação aos acusados. Paula Souza sugere que o parecer volte à comissão para que esta ouça a defesa deles. Lino Coutinho concorda, mas faz uma ressalva: de que não estão a julgá-los como ministros, mas como homem comum, pois é esse o poder que a Câmara tem. Ernesto França concorda com a distinção e vai além, pedindo que o parecer não volte à comissão, pois a Câmara, ao elaborar as congratulações ao Imperador pela demissão destes homens, já teria emitido seu juízo sobre eles.

O que estes deputados estão a defender é, nitidamente, que se fuja das formalidades exigidas para o processamento dos ministros de estado. Não é difícil entender o porquê, conhecendo-se o resultado da empreitada de 1829, que resultara em nada. Os deputados percebem que a escolha da forma, aqui, terá estrita relação com o resultado. Não se trata apenas de produzir ou não provas ou garantir a defesa do acusado, mas de fazer repousar na Câmara a decisão final.

Luiz Cavalcanti defende que o assunto volte à comissão, para que "se ouça por escrito a sua defesa [de Clemente Pereira] (...), sem o que não podemos julgar”. Fala em “cópia da acusação" e "corpo de delito", defendendo que se proceda com "formalidade" e que haja no "processo aquilo que se faz com os ministros de estado".

\footnotetext{
70 Antônio Francisco de Paula de Holanda Cavalcanti de Albuquerque (1797-1863) nasceu em Pernambuco, eleito deputado pela sua Província natal para as três primeiras legislaturas da Assembleia Geral, de 1826 a 1837. Em 1838, foi nomeado senador. Foi Ministro do Império várias vezes entre 1830 e 1863. Foi também conselheiro de Estado. Obteve o título de Visconde de Albuquerque.

${ }^{71}$ Antônio Paulino Limpo de Abreu, Visconde de Abaeté (1798-1883) era português, nascido em Lisboa. Estudou Direito na Universidade de Coimbra. Regressou ao Brasil em 1820, iniciando sua carreira na magistratura. Foi Desembargador da Relação da Bahia, deputado por várias legislaturas entre 1826 e 1848 e presidente de província (1833-5). Participou da Revolução Liberal de 1842, tendo sido deportado para Portugal. Regressou e foi ministro do Império, da Justiça, dos Estrangeiros e da Marinha, e também do Supremo Tribunal de Justiça (1846-8). Foi escolhido senador em 1847.

${ }^{72}$ APB, 14 de maio, p. 135 e ss.
} 
Os liberais discordam. Vasconcelos toma a palavra para responder chamando a forma de proceder de Cavalcanti de "formalidade do direito romano e canônico", às quais se declara não estar preso. Acaba por concordar que a comissão ouça a defesa do acusado, "a fim de que não se diga que se postergaram as fórmulas". Holanda Cavalcanti o apoia, defendendo um processo "sumaríssimo, moderno", pois não se está a impor pena aos acusados, mas a fazer "juízo exato sobre as qualidades que se exigem". Para ele, trata-se de "objeto de polícia interna".

Lino Coutinho, ao defender o ponto de vista acima mencionado, motiva os colegas a abrirem mão de tais garantias, normalmente defendidas por eles (homens liberais e constitucionais), ironizando o fato de que:

"os absolutistas agarram, enforcam, processam imediatamente, quando eles o querem e então não há garantias individuais; mas se os liberais ficam um pouco em cima e agarram um absolutista, ei-lo clamando pelas garantias individuais da constituição, ei-lo bradando - 'vós não cumpris com o vosso sistema, vós me quereis julgar sem me comunicardes a culpa, etc., etc.!' Mas maldito diabo, tu fazes o que queres, prendes os liberais, os tiranisas, os desterras só porque assim entendes, e quando eles estão em cima, lembras-te de clamar pelas garantias individuais”.

A fala é bastante interessante. De um ponto de vista da coerência esperada entre prática e ideias, adivinha-se uma traição, uma vontade de dispensar as garantias constitucionais no caso de Clemente Pereira, um absolutista. Entre outras palavras, o tom irônico sugere que o constitucionalismo só valeria para seus defensores, talvez uma adoção instrumental de tal ideário. Justo ou não esse juízo, sua verossimilhança se baseia no contraste que haverá entre essa posição aqui descrita e a de outros deputados que se apegarão às garantias, independente de seu apreço pelo acusado.

$\mathrm{O}$ assunto então volta à comissão ${ }^{73}$ que expede um ofício, datado de 15 de maio, com as acusações em termos genéricos, falando em "dúvida, que ocorre na verificação

\footnotetext{
73 Os deputados passam a tratar de outros itens da ordem do dia, mas a expressão "ministério clementino" ainda é reiterada por Vasconcelos e Lino Coutinho para depreciar decisões do governo, quando estão a discutir, respectivamente, a regulamentação do uso que as províncias deveriam fazer das sobras
} 
do Diploma de V. Exa., por ser suspeito de haver, durante o Ministério, praticado atos anticonstitucionais, e que tendiam à destruição do atual Sistema, ou indiretamente protegido os Absolutistas" - os deputados chegaram a discutir, no final da sessão do dia anterior, a elaboração de quesitos, mas decidiram que estes ficariam a cargo da comissão.

O documento de defesa de Clemente Pereira data de 19 de maio ${ }^{74}$ e começa pela questão de direito: conforme já mencionamos, ele lança a argumentação de que as instruções são recomendação feita ao eleitor ${ }^{75}$. Sobre as questões de fato - as acusações relativas ao seu ministério - ele se deterá principalmente nas alegações de ter defendido grupos tidos por absolutistas do Ceará e Pernambuco. Sobre as comissões militares, sua defesa remete a documento anexo expressando seus "sentimentos contra a criação de uma comissão militar para o Ceará - voto a que se deve o não se ter criado, e ficar sancionado o princípio de se não poderem criar outras - mostrará que quem assim sabia respeitar os princípios constitucionais não pode, sem injustiça, ser taxado de suspeito contra a constituição".

É significativo que tão pouca atenção seja dada, no documento, ao que Clemente pereira sabia ser a principal acusação feita a ele. Além disso, apesar de afirmar que fora contra a criação das comissões, ele as defendera um ano antes diante da própria Câmara - o que não passará em branco perante seus detratores, como veremos. Em suma sua estratégia de defesa é centrada na questão de direito: a alegada impossibilidade de ser julgado por seus pares; em relação às acusações, Clemente Pereira é evasivo, aproveitando-se da falta de provas concretas dos crimes levantados contra ele.

Para reforçar que sua atuação era pautada pelos princípios constitucionais ele relembra sua colaboração na proclamação da independência e passa a elencar os atos de sua administração que provam que combateu o absolutismo: as medidas para a implementação dos cursos jurídicos, instrução primária e atuação das câmaras

orçamentárias e da regulamentação dos correios (afirma que Clemente Pereira teria legislado sobre o assunto, criando cargos e aumentando ordenados). Anais, p. 154.

${ }^{74}$ Utilizamos a transcrição de Carvalho (2002) feita a partir do documento original, do acervo da Biblioteca Nacional (Ms II - 30,31 4 Doc. $\mathrm{N}^{\mathrm{o}}$ 1).

${ }^{75}$ A argumentação é bastante extensa, mas não é do escopo do trabalho analisá-la. Carvalho a transcreve na íntegra (Carvalho, 2002, p. 121 e ss.) 
municipais e dos juízes de paz, "liberais instituições", "verdadeiras bases sobre que assenta o sistema da representação nacional" (Carvalho, 2002, p. 135).

A comissão responsável - instituída apenas para analisar a questão - apresenta seu parecer em 21 de maio $^{76}$. O texto começa por registrar a dificuldade que encontrou o grupo em ser parcial na análise de tais pessoas, tendo em vista terem elas "praticado tantos atos contrários aos interesses, e prosperidade da Nação, [que] tem acarretado sobre si um chuveiro de maldições". Diferentemente do primeiro, este parecer lista as acusações: a nomeação ou manutenção de "presidentes mal postos ou conservados na opinião publica por ineptos, ou inimigos do sistema jurado" e de "comandantes militares desacreditados por seus atos arbitrários, e por decidido aferro ao absolutismo"; proteção e acobertamento de "periodistas infames" que espalhavam "máximas contrárias ao sistema constitucional" e difamavam "os liberais, e com particularidade os deputados mais defensores das liberdades públicas"; tolerância do Ministério para com "uma sociedade liberticida" em Pernambuco. Tudo com o fim de "preparar os povos para a queda da constituição", enquanto homens "escravos do poder" eram agraciados com "honras e empregos de Estado".

Mas "impondo-se imparcialidade", a Comissão analisa da seguinte maneira a situação: em relação a algumas acusações (nomeação de determinadas autoridades provinciais) as acusações não procediam; sobre atos do ministério de condescendência com a perseguição de liberais, afirmava que a defesa de Clemente Pereira o salvava da "suspeita de conspirar diretamente contra o sistema jurado", mas não "do crime de responsabilidade e de incorrer na indignação pública". Note-se que não há menção a duas acusações: aos esforços de obstar a aprovação do orçamento e do patrocínio das comissões militares.

Por fim, a comissão afirmava que Clemente Pereira fora "um péssimo ministro de estado, que mais quis lisonjear o poder para conservar-se no mando, do que zelar os interesses do mesmo Poder, e que, se fez bem à Nação, maiores males ainda a fez experimentar", motivo pelo qual "com bem dor do seu coração" a Comisso se via, no entanto, na "precisa necessidade de curvar-se à Lei, ceder aos gritos da sua consciência"

\footnotetext{
${ }^{76}$ APB, 21 de maio, p. 185.
} 
para "declarar que não podem ser classificados em nenhuma das exceções marcadas na Constituição" os atos do acusado. Confirmava que o artigo das Instruções no qual se baseava a acusação constituía, como argumentava o acusado, "recomendação na forma que ambas as Câmaras o tem sempre entendido, e nesse caso a sua execução só pode ser reservada ao juízo, e consciência dos eleitores". Com isso concluía confirmando o parecer anterior, pelo qual o diploma do acusado deveria ser considerado válido.

A comissão ${ }^{77}$ não deixa dúvida de concordar com os demais deputados liberais, no juízo extremamente negativo acerca do ministério em questão. Mas fundamenta sua decisão em razões jurídicas, argumentando, ainda que de maneira um pouco difusa ao longo do documento, que os atos levantados pelos opositores de Clemente Pereira não podiam ser classificados como atentado ao sistema.

Como se pode imaginar, uma longa discussão se seguiu acerca do parecer. Na data de sua apresentação o debate foi breve e decidiu-se apenas a impressão do documento. O mérito voltou à ordem do dia em 29 de maio ${ }^{78}$, quando vários deputados se opuseram ao parecer. Xavier de Carvalho acusa Clemente Pereira de cometer perjúrio ${ }^{79}$ ao afirmar, sem seu documento de defesa, que fora contra as comissões, pois ele mesmo se manifestara na Câmara para defendê-las. Feijó defende o parecer da Comissão que integrou, sempre argumentando os perigos do precedente de se permitir que os deputados julguem seus pares com base em suspeitas.

A discussão é retomada em 01 de junho ${ }^{80}$, e tomam a palavra para defender o acusado Evaristo Ferreira da Veiga, José Martiniano de Alencar, Paula Souza e Joaquim Gonçalves Ledo. Os três primeiros sustentam sua argumentação em questões que podemos chamar de formais: a legalidade e legitimidade da acusação, a presunção de inocência e a falta de provas contra o acusado, pontuando em suas falas, porém, sua desaprovação da atuação de Clemente Pereira. Ledo é o único a defender no mérito seu correligionário.

\footnotetext{
${ }^{77}$ Essa comissão tinha um membro em comum com a anterior, Ernesto Ferreira França, que nas duas vezes foi voto vencido - ou seja, defendeu a culpa do acusado. Isso traz à tona a importância dos outros membros, tendo em vista que o grupo era composto por três deputados - diferentemente da comissão do primeiro parecer, a de poderes, que contava com cinco integrantes - sendo eles Diogo Feijó e José Martiniano de Alencar.

${ }_{79}^{78}$ APB, 29 de maio, p. 264 e ss.

${ }^{79}$ Idem, p. 265.

${ }^{80}$ APB, 01 de junho, p. 276 e ss.
} 
Em 02 de junho há novo e derradeiro debate sobre a questão, com ataques e defesas proferidas basicamente pelos mesmos deputados e centradas nos argumentos já mencionados, mas vale notar a fala de Feijó:

Sabemos que preceitos são aquelas coisas que o homem é obrigado a fazer pela natureza das coisas, mas que não é necessária a persistência dele, e os mesmos autores que têm tratado de direito natural sustentam isto; primeiramente quando se pretende trazer para a acusação de um homem que serve ou tem servido grandes empregos, a narração dos fatos pelos quais ele parece criminoso, nada pode haver mais fácil, mas quando aparece aqui um homem que não tenha sido ministro, ou outro qualquer grande emprego, ninguém vai examinar a sua conduta examinando-se unicamente se ele é inimigo do Brasil, porque vícios, crimes ou delitos, mais ou menos, todos os homens têm ou podem ter ${ }^{81}$.

O destino de Clemente Pereira é julgado nessa mesma sessão, e seu diploma é validado por 42 votos favoráveis contra 35 contrários $^{82}$. Em 03 de junho de 1830 ele toma posse. Não foi possível analisar em todas as sessões seguintes suas participações, mas focamos no debate mais relevante para os fins desse trabalho: o do Código Criminal. A questão será abordada no capítulo seguinte, mas adiantamos que alguns de seus aspectos foram debatidos pelos deputados em maio, sem a presença dele. Quando o assunto volta à pauta, em setembro, ele está presente, mas não se manifesta. Os debates são protagonizados por Vasconcelos, seu inimigo, e autor do projeto adotado pelo legislativo.

\footnotetext{
${ }^{81}$ APB, 02 de junho, p. 299. Apesar de pouco explicitada nesse momento, a menção lança luz em uma questão não irrelevante: a situação desafiadora em que os homens chamados a exercer os cargos de ministro se encontravam; de lidar com um sistema que lhes imputava responsabilidade por seus atos, resguardando o imperador, mas que não lhes garantia autonomia, uma vez que eram livremente nomeados e demitidos pelo monarca. Mas mais do que isso, era conhecido o fato de que D. Pedro se imiscuía cotidianamente nos assuntos do governo, exatamente o pecado que a configuração do Poder Moderador tentava salvar. Mas é provável que o que motiva de fato a fala de Feijó é a diferença de posições entre aqueles que defendem suas ideias no Parlamento, arvorados nas liberdades do caro do deputado, e aqueles que têm por ofício o dever de tomar decisões, a considerar e a pesar todas as contingencias impostas pela realidade. $\mathrm{O}$ trânsito entre esses dois mundos será realizado por alguns homens; aqui já havia sido completado por Clemente pereira; em breve se dará para Feijó e, mais tarde, também para Vasconcelos, não sem consequências para as posições que defendia, como se sabe.

${ }^{82}$ Não é possível conhecer todos os votos, mas alguns deputados declaram suas posições; na ata de 03 de junho consta a declaração conjunta de 13 desses deputados (p. 312).
} 
É a partir deste momento que se dá o agravamento da luta entre Coroa e Parlamento. Durante todo o período acima descrito Clemente Pereira se manteve próximo ao Imperador, apoiando suas atitudes, motivo pelo qual era odiado e combatido conforme pudemos ver. Sua vitória pode ser interpretada pela força dos argumentos de seus defensores, como Feijó e Evaristo: foi uma vitória das prerrogativas do legislativo. Apesar da reprovação geral de seu ministério manifestada tanto por seus inimigos quanto aqueles que se colocaram momentaneamente ao seu lado, a maioria da Câmara não apoiou a ideia de excluir um de seus membros com base num juízo político sobre ele. Fica claro, pela escolha do caminho para julgá-lo - o questionamento de seu diploma e não sua responsabilização como ministro - que não se tratava de crime propriamente, mas de impor-lhe consequências por seu posicionamento politico passado, ao que os termos das Instruções, muito mais vagos e adaptáveis às circunstâncias ("suspeito à causa do Brasil") se prestavam. A seguir esse caminho os deputados ficariam livres para julgar, de acordo com suas consciências e livres de provas. Foi essa liberdade da maioria de excluir seus opositores que pareceu perigosa a alguns, e enfraquecedora do próprio Parlamento.

A julgar pelos relatos de Tobias Monteiro, em 1829 o monarca obteve uma vitória pessoal quando a Câmara não conseguiu condenar um ministro; podemos dizer que em 1830 foi o Parlamento enquanto instituição que saiu fortalecido quando parte dos deputados não conseguiram excluir um de seus pares. Não podemos nos esquecer, é claro, que esse par era também um ex-ministro, político experiente e versátil, e pode-se imaginar que desempenhou um papel importante no resultado o poder que Clemente Pereira certamente ainda possuía. Mas há motivos para se levar a sério os argumentos levantados por Feijó e Evaristo da Veiga, não só do ponto de vista de sua sinceridade e verossimilhança, mas também de seu papel articulador na possibilidade do resultado favorável à posição que defendiam.

Esse embate se deu durante o período de curta conciliação entre Coroa e Parlamento, o relativo ao Ministério Barbacena. Foi ele o responsável pela conciliação entre o monarca e os liberais, que a cada dia iam ganhando desenvoltura no exercício de suas novas atribuições, dando corpo à nova configuração política. 
Fruto dessa coordenação foi a aprovação do Código Criminal, em outubro, fim da sessão legislativa. Mas foi também seu último lance: o gênio imperial mais uma vez se voltou para seus impulsos menos constitucionais e a demissão de Barbacena, com lances dramáticos, rompeu a aliança. Um dos pontos constantes deste embate, como já comentamos, era o contingente das forças armadas, tendo em vista que a força da Coroa, em última instância, era militar. Residirá aqui o estopim de mais um conflito que terá como pivô nosso personagem.

Mas este novo conflito será antecedido pelo desfecho da luta: instaurada nova crise entre os poderes, o próprio D. Pedro perceberá que seu apoio popular já não era o mesmo; as dúvidas que pairavam sobre seu caráter de "Defensor Perpétuo da causa do Brasil" se tornam cada vez maiores. Em última instância, diante da pressão dos liberais e da opinião pública para que cedesse - restaurando o ministério moderado que ele demitira - ele abdicará do trono em abril de 1831.

No mesmo ano, em maio, logo no início da sessão legislativa, Clemente Pereira é atacado. Foi acusado de ter usurpado os poderes do legislativo e dissipado bens públicos quando Ministro da Guerra, cargo que exercera entre agosto e dezembro de $1829^{83}$, por ter mandado recrutar homens para as tropas sem lei que o autorizasse e por ter comprado armas sem aprovação de orçamento para tanto ${ }^{84}$. Em sua defesa Clemente Pereira afirmou que o recrutamento se dera para a reposição do efetivo, sem ter significado aumento do mesmo. Em relação à compra de armas alegou que era necessária e urgente, tendo sido realizada com restos a pagar, ou seja, sem burla ao orçamento (Carvalho 2002, p. 147).

A comissão especialmente designada para analisar a denúncia, formada por Limpo de Abreu, Lino Coutinho e Vasconcelos, concluiu pelo seu cabimento ${ }^{85}$. Segue-se extensa discussão nessa e nas próximas sessões. A maioria dos deputados vê criminalidade em ao menos um de seus atos, se não nos dois. Apenas dois deputados o defendem, ambos argumentando que o ministro agira dentro da legalidade na falta da lei

\footnotetext{
${ }^{83}$ A denúncia, a princípio, também incluía seu sucessor, o Conde do Rio Pardo, mas desde o primeiro parecer apresentado até o envio da acusação ao Senado só se trata do caso de Clemente Pereira.

${ }^{84}$ APB, 20 de junho, p. 160.

${ }^{85}$ Ata de 21 de julho, p. 262.
} 
de fixação das forças armadas, não instituída naquele ano ${ }^{86}$, e porque seus atos foram feitos no interesse público ${ }^{87}$.

Pode-se notar que para os inimigos de Clemente Pereira - Limpo de Abreu, Lino Coutinho e Vasconcelos - essa era finalmente a oportunidade de impor-lhe as consequências pelo seu absolutismo. O próprio Lino Coutinho, ao trazer à Câmara a acusação, afirma que:

Que no ano passado se duvidara acusá-los por não ser ocasião para isso; porém que agora aproveitando-se as circunstâncias, eles deviam ser para que tivessem a recompensa de seus altos feitos ${ }^{88}$.

Muitos deputados, ao discursarem sobre a questão, não se restringem aos fatos que deram ensejo à denúncia, mas fazem menção aos sentimentos que eles mesmos e a "opinião pública" tinham do ministro. Existe um clima de acerto de contas com toda a trajetória de Clemente Pereira, mas não se pode dizer que seus atos enquanto ministro da guerra fossem apenas um pretexto para tanto uma vingança. Tratava-se sim de questão cara aos liberais, como já mencionamos: a participação do Legislativo na definição da dimensão das forças armadas era um dos pilares da monarquia constitucional. Da leitura das atas percebe-se que essa exigência sempre fora feita ao governo, e causava inflamados debates entre os poderes. $\mathrm{O}$ ministro, ao ter administrado a questão à revelia do Parlamento o sabotara nessa missão que lhe era cara.

E o tema era central não só no Brasil, mas em outros sistemas parlamentares. Como menciona Carneiro da Cunha:

Nos governo monárquicos constitucionais era esta uma atribuição exclusiva dos representantes da nação; e que mesmo na Inglaterra, onde o

\footnotetext{
${ }^{86}$ Segundo Monteiro, o encerramento do ano sem a votação da lei de meios teria sido a vingança do parlamento contra a vitória do Imperador que logrou livrar seu ministro da guerra do processo de responsabilidade. Em resposta, o Imperador proferiu lacônica fala de encerramento (“...”), causando mal estar entre os poderes.

${ }^{87}$ APB, dias 26 de julho e 04 de agosto.

${ }^{88}$ APB, 09 de maio, p. 17.
} 
monarca gozava de muitas prerrogativas, não tinha esta; podia sim declarar a guerra, mas não continua-la se a câmara não lhe decretar os meios ${ }^{89}$.

Não é possível, nem é nosso objetivo, concluir se Clemente Pereira era culpado ou não, ou se agiu de maneira "pouco constitucional", ainda que no interesse da pátria. Pela análise dos discursos na Câmara pode-se identificar que havia elementos para sua acusação, como também havia interesse de alguns deputados de finalmente alijá-lo do poder. Por outro lado, não eram irrelevantes ou totalmente falsos os argumentos de sua defesa, o que se deduz da fala dos deputados que se alternavam em reprovar apenas uma das acusações, pelo fato de ter sido absolvido no Senado e também porque a compra das armas foi mais tarde aprovada nas instâncias competentes.

Mais interessante é identificar e relacionar as questões que estavam em jogo: no âmbito institucional, as disputas entre os poderes. Na análise do contexto político, a mudança no discurso dos deputados: se em 1829 e 1830 o ataque aos ministros era sempre cuidados em salvaguardar o Imperador D. Pedro, agora a reprovação do Príncipe D. Pedro estava presente em todas as falas, e muitos parlamentares faziam menção á necessidade de julgar e condenar muitos - ou todos - os seus ex-ministros. Relacionado a tudo isso e do ponto de vista da posição de Clemente Pereira pode-se dizer que ele foi nesse momento uma espécie de bode expiatório e símbolo da caça às bruxas que as novas forças politicas predominantes intentaram promover contra os sobreviventes do absolutismo $^{90}$.

Mas é certo que os interesses políticos e a defesa do governo - agora, após a abdicação, já chamado abertamente de absolutistas pelos deputados - desempenhou, mais uma vez, um papel decisivo: a acusação foi apresentada ao Senado, tendo sido enviada uma comissão de cinco deputados para tal tarefa ${ }^{91}$. O órgão só veio a analisá-la no ano seguinte, em junho de $1832^{92}$, sendo absolvido pela unanimidade dos 35

\footnotetext{
${ }^{89}$ APB, 26 de julho de 1831, p. 269.

${ }^{90}$ Nos mesmos meses de 1831 em que discutem a responsabilidade de Clemente Pereira os deputados também debatem projeto de lei para remover os empregados públicos que se mostraram contrários à independência, de autoria de Paula Araújo. O projeto entra na ordem do dia em 23 de junho (p. 177). Rebouças, Andrada e Silva, Perdigão, Cunha Mattos, Carneiro da Cunha e Araújo Lima, entre outros, o rejeitam, mas Ferreira da Veiga, Paula Souza, Costa Ferreira e Vasconcelos.

${ }^{91}$ Eleitos nas sessões de 20 de agosto (p. 52) e 27 de setembro; com posição final: Limpo de Abreu, Carneiro Leão, Xavier de Carvalho, Ferreira da Veiga e Ernesto.

${ }^{92}$ AS, 05 de junho de 1832 , p. 319 e 09 de junho de 1832, p. 289.
} 
senadores. Das sessões da Câmara ele só voltaria a participar em agosto de 1833 (Carvalho 2002, p. 152).

Em 1835 se torna deputado provincial, integrando a $1^{\text {a }}$ Assembleia Provincial do Rio de Janeiro, instituição fruto do Ato Adicional de 1834 e que ganhara atribuições das Câmaras Municipais e do governo central. Mais um lance interessante na sua trajetória: eclipsado, pelos liberais, da cena da Assembleia Nacional, ele encontrará abrigo no edifício erigido pelos mesmos liberais. De sua atuação nos anos de 1835 a 1838 destacamos que por sua iniciativa a Vila Real de Praia Grande, onde começara sua vida política, se tornou capital da Província (idem, p. 153).

Em 1838 é eleito Provedor da Santa casa de Misericórdia ${ }^{93}$ e volta a ser deputado pelo Rio de Janeiro, eleito pelo mesmo Partido Conservador de seu inimigo Vasconcelos. Os tempos eram outros, bem diferentes. Enquanto Clemente Pereira atuava na província os liberais se cindiram. Vasconcelos foi aos poucos mudando de posição; já durante os debates sobre o Ato Adicional demonstrava sua preocupação com a radicalização de algumas posições que, para ele, levariam à anarquia. Durante a regência de Feijó Vasconcelos romperá definitivamente com seus ex-companheiros e em 1837 liderará a oposição, iniciando os debates sobre a reforma do Código de processo de 1832, grande obra liberal. Na regência de Araújo Vianna ${ }^{94}$ ele será o poderoso ministro do Império e da Justiça, e fundará o partido que predominará na legislatura de 1838 a 1841 . Essa será a porta de reentrada de Clemente pereira na cena política nacional.

Novamente deputado, Clemente Pereira integra a comissão que discute o Código Comercial, assunto que já tramitava na Câmara desde 1836. Engrossa também, no Plenário, o coro de críticas à organização judiciária, que será finalmente reformada em 1841, ano em que é reeleito deputado e se torna novamente Ministro da Guerra. Sua atuação será contundente, sempre combatendo os ecos das acusações de uma década atrás. Em 1843 também assumirá o Ministério da Marinha.

\footnotetext{
${ }_{94}^{93}$ Instituição que tinha o privilégio dos enterros e mantinha cemitérios próprios.

94 Cândido José de Araújo Viana, Marquês de Sapucaí, viveu entre 1793 - 1875, tendo nascido em Congonhas de Sabará, Minas Gerais. Formou-se em Direito na Universidade de Coimbra e foi juiz de fora, desembargador da relação, Ministro da Fazenda, Conselheiro de Estado, Ministro do Império, Ministro do Supremo Tribunal de Justiça, Ministro da Justiça, deputado constituinte, deputado geral, presidente de província e senador a partir de 1840.
} 
Importante lembrar que em 1842 a Câmara é dissolvida pelos conservadores, no poder desde 1840 com o golpe da maioridade. O relatório no qual se baseou a decisão é assinado pelo Marques de Paranaguáa ${ }^{95}$, Araújo Vianna, pelo Visconde do Uruguai ${ }^{96}$, Aureliano Coutinho ${ }^{97}$ e Clemente Pereira; é fato que ele está de volta ao topo do poder. Tanto é que em 1843 se torna senador pela Província do Pará.

É no Senado que ele protagonizará os debates sobre o Código Comercial, que inicia sua tramitação na casa três anos depois, em 1846, com seu auge em 1848 e aprovação em 1850. Dessa participação trataremos no terceiro capítulo.

Em 1850 será nomeado o primeiro presidente do Tribunal de Comércio da Capital, cargo que exercerá até 1854, ano de sua morte. Nos mesmos anos atua como membro extraordinário do Conselho de Estado, e como senador, integra nesses anos as Comissões de Marinha e Guerra e a de Comércio, Agricultura, Indústria e Artes.

\footnotetext{
95 João Lustosa da Cunha Paranaguá (1821- 1912) nasceu em Nossa Senhora do Livramento, no Piauí. Cursou Direito na Faculdade de Olinda e foi juiz, Ministro Justiça, dos Negócios Estrangeiros, da Guerra, da Fazenda, presidente de província, deputado provincial, deputado geral e senador.

${ }^{96}$ Paulino José Soares de Sousa, Visconde do Uruguai. Nascido em 1807 em Paris, iniciou seus estudos em Coimbra em 1823, concluindo-os em 1830 na Faculdade de Direito de São Paulo, onde se formou em 1831. Foi juiz da corte, presidente da Província do Rio de Janeiro entre 1836 e 1840, deputado geral pelo Rio de Janeiro eleito em 1836, ministro da Justiça em 1840 e de 1841 a 1843, Foi ministro dos Negócios Estrangeiros de 1849 a 1853, senador do Império em 1849 pelo Partido Conservador e conselheiro de Estado em 1853. Recebeu o título de visconde de Uruguai no ano seguinte. Em 1855 foi enviado a Paris para tratar da questão do Oiapoque e de problemas de limites do Brasil com a Guiana Francesa. Publicou duas importantes obras, os "Ensaios sobre o direito administrativo", em 1862, e "Estudos práticos sobre a administração das províncias do Brasil", de 1865 (Carvalho, José Murilo. "Formadores do Brasil: Visconde do Uruguai”. 2002. São Paulo: Ed. 34).

${ }^{97}$ Aureliano de Sousa e Oliveira Coutinho, Visconde de Sepetiba. Nascido no Rio de Janeiro em 1800, formou-se em Direito na Universidade de Coimbra. Foi deputado geral entre 1830 e 1833 e de 1838 a 1841. Nomeado senador em 1843, foi presidente das províncias de São Paulo (1831) e Rio de Janeiro (1844-8). Ocupou vários ministérios entre 1833 e 1841.
} 


\section{CAPÍTULO 2 \\ O CÓDIGO CRIMINAL - 1826 A 1830}

\subsection{A codificação penal no século XIX}

Como já referido no início desse trabalho, o século XIX é marcado pela codificação. Em matéria penal não é diferente: entre o final do XVIII e início do XIX surge na Europa um ímpeto reformador na matéria, representado principalmente pelo código penal da Toscana de Leopoldo II, de 1786 e pelo projeto de Mello Freire ${ }^{98}$, do mesmo ano.

Esses modernos códigos foram antecedidos por um esforço de sistematização legislativa que lhes abriram as portas, mas com eles não se confundem; essas obras vinham sendo realizadas em vários países com o objetivo de organizar a confusão de leis existente. A crescente importância do direito nacional e a necessidade de seu ensino podem ser indicadas como motivadoras desse movimento, levado a cabo, entre outros juristas, pelo próprio Melo Freire em Portugal, em 1789, e por Blackstone na Inglaterra, em 1765 (Lopes, 2004, p. 151). Esses textos tinham por característica uma visão geometrizante, taxonômica e sistematizadora dos elementos do direito (Queiroz 2009, p. 77).

Isso significa dizer que o direito passa a ser visto como possuidor de elementos estruturantes e irredutíveis, dos quais se deduz sua disciplina, um conjunto de princípios gerais organizadores e comuns a toda a ciência jurídica, que lhe dava conjunto e sistematicidade. Desses pontos de partida, ou desse tronco, nasceriam os diversos ramos particulares relativos a assuntos específicos.

Estamos falando aqui do jusnaturalismo, a fundamentação do direito na razão natural, em suas distintas configurações (Lopes, 2004 e Queiroz, 2009), razão que "seria exercida por um só, o Legislador", a reformar os costumes e suplantar a "profusão de opiniões, doutrinas, interpretações e costumes locais e apresentar a solução racional por

\footnotetext{
${ }^{98}$ Pascoal José De Mello Freire Dos Reis viveu entre 1738 e 1798 e foi um dos principais nomes do direito português. Pertenceu ao Conselho de S. M. a Rainha D. Maria I, foi Desembargador da Casa de Suplicação e professor da Faculdade de Direito da Universidade de Coimbra.
} 
excelência”, ideal que será sustentado pelos sobramos no interesse da unificação dos estados.

O Iluminismo levará esse movimento a consequências mais profundas; além de reformar o direito, o legislador racional vai reformar a realidade. A valorização da atividade legislativa do soberano nos termos expostos abrirá as portas para que essa seja a forma eleita para corrigir, modificar, melhorar a realidade, e a codificação será o "ponto mais acabado" desse movimento (Lopes, 2004, p. 151 e ss). Assim, a forma inaugurada pelas sistematizações de organizar o direito será herdada pelos códigos, que assumirão "uma forte vocação reformadora que até então não tinham"; pelas mãos dos soberanos, a codificação, nesses termos, representará um “absolutismo legislativo", que marcou o século XVIII (Lopes, 2009b, 152).

Essa consolidação da jurisdição real e da soberania politica do rei terá muitas vezes, como ponto de partida, o direito criminal, por significar "a obtenção do monopólio jurisdicional sobre a definição de ilícitos jurídicos ("crimes"), seu processamento e sua punição" (Queiroz, 2009, p. 71), o que se relaciona com a proliferação de diplomas na esfera criminal. Por outro lado, os códigos também representam a luta contra o arbítrio judicial (Bravo Lira, 2004, p. 37), são "instrumento de proteção dos súditos em face dos poderes punitivos do soberano" (Queiroz, 2009, p. 85) ${ }^{99}$.

Sob esse aspecto garantista as mudanças também serão inauguradoras de um novo tempo, e nesse sentido, revolucionárias: a nova visão da pena a contrastar com os excessos de punição até então vigentes, movimento capitaneado por Beccaria, e o

\footnotetext{
${ }^{99}$ Esses dois lados da codificação criminal representaram projetos políticos em disputa, tanto na constituição teórica do direto criminal ("consolidar a exclusividade do poder criminal soberano versus limitar o exercício desse mesmo poder através do próprio direito criminal") quanto na concreta definição do conteúdo dos códigos; matéria exemplar dessa luta é a definição dos crimes políticos; veja-se, para o caso do código de 1830 no Brasil: segundo Thomas Flory, "ele fora pensado em parte para se adaptar às metas políticas da oposição ao imperador, fim claramente expresso nos artigos a respeito da definição e do castigo dos delitos políticos. Com o pretexto de revisar as leis desumanas de Portugal, os liberais, que se opunham ao imperador e queriam restringir seu poder para perseguir seus inimigos políticos, inclinaram o código no sentido de favorecer os "dissidentes" e "revolucionários políticos". Retomando as discussões feitas na câmara, e considerando a opção pela exclusão da pena de morte nos casos de crimes políticos (prevista por Vasconcelos em seu projeto), parece lícito conjecturar que a importância política do Código - ou melhor, sua centralidade no combate político ao imperador - era preocupação fundamental para grande parte do plenário". Apud Dantas, no prelo, p. 19. Thomas Flory, El juez de paz y el jurado en el Brasil imperial. Control social y estabilidad políticaen el nuevo Estado. México, Fondo de Cultura Económica, 1986.
} 
advento do princípio da legalidade como indissociável do direito penal, como veremos mais adiante.

As principais iniciativas surgem em diferentes partes: em 1786, o Código penal da Toscana, de Leopoldo, também chamado de Leopoldina; no mesmo ano, o projeto de por Mello Freire, que apesar de não ter se tornado Código teve muita influência, especialmente no Brasil. Em 1787 nasce a Ordenança Penal Austríaca de José II, chamada Josefina. Em 1791 a Assembleia nacional Constituinte da França aprova um Código Penal, substituído em 1810 pelo diploma napoleônico ${ }^{100}$; em 1803 surge o Código Penal Austríaco (marcado pela influência do jurista Franz von Zeiller) e em 1813 o Código Penal Bávaro (que por sua vez trazia a marca de P.J.A. Feuerbach).

Importa notar que entre todos eles, o título de primeiro código penal moderno é atribuído ao código austríaco de 1787 (Hespanha, 1993); ele "marca definitivamente a chegada da consolidação em sentido estrito, em lugar do mero remanejamento ou certificação das normas anteriormente existentes" (Queiroz, 2009, p. 82). Ele se divide em parte geral e parte especial e traz uma separação substancial entre direito material e direito processual, sendo importante notar que essa matéria agora vem em segundo lugar, depois do direito substantivo. A parte geral também estava cindida, distinguindo o ilícito criminal dos demais ilícitos jurídicos, chamados infrações de polícia. Essa distinção, apesar de criticada por alguns por prejudicar a sistematicidade do código, fortaleceu o processo de autonomia do direito criminal, até então não existente (Queiroz, 2009, p. 131).

Essas caraterísticas fazem com que o Código Austríaco seja um marco não só da codificação moderna em sentido amplo, mas da constituição histórica do direto penal moderno, que se pode identificar nesse período: uma disciplina autônoma, ramo do direito público, que comporta uma divisão entre parte geral e parte especial, com distinção entre o direito processual e material, erigida sobre o princípio da legalidade (Queiroz, 2009).

\footnotetext{
${ }^{100}$ Segundo Bravo Lyra, os primeiros códigos eram marcados pela ilustração católica e nacional, características dos países onde surgiram, Portugal e Áustria, enquanto o código francês de 1791 é marcado por uma "vertente irreligiosa e cosmopolita", característica da Ilustração francesa (2004, p.67).
} 
A organização entre parte geral (princípios) e parte especial é produto da visão geometrizante do direito, como acima exposto, ainda que o conteúdo desses princípios que serão os fundamentos da emancipação do direito penal - não fosse era unânime entre os juristas. O direito penal atual define as regras gerais de crime e pena na parte geral e cada delito na parte especial, organizando-os pelo bem jurídico protegido e elencados de acordo com sua gravidade (sendo os mais graves os crimes contra a vida). No fim do século XVIII essa visão ainda não predominava, mas veremos sua afirmação.

Algumas sistematizações legislativas traziam na "parte geral" o direito criminal e na parte "especial" as regras processuais (Queiroz, 2009, p. 132). No final do XVII já teremos a configuração contemporânea do direito processual: a "efetivação prática dos comandos da legislação criminal” (idem, p. 77).

\section{$3.2 \mathrm{O}$ código criminal brasileiro}

A Constituição de 1824 determinava, em seu artigo 179, XVIIII ${ }^{101}$, que se elaborasse um Código Civil e um Código Criminal. Deles, o primeiro a ser criado foi o Código Criminal; essa primazia não é fortuita, explica-se pelo contexto jurídico e político da codificação criminal como acima exposto. Ao mesmo tempo em que participava desse movimento de concentração do poder real nas mãos do monarca e fortalecimento de suas atribuições jurisdicionais, o Brasil vivia um rearranjo de forças políticas a partir de sua separação de Portugal.

A gestação do Código brasileiro vai de 1824 - quando a Constituição determina sua necessidade e institui os princípios que o deverão guiar - até 1830, ano de sua promulgação. Esse tempo pode parecer curto quando comparado ao de outros diplomas - o Comercial foi debatido por 30 anos e o Civil, por meio século - mas não foi isento de dramas políticos e jurídicos. A análise mais detida do desenrolar dos debates que o antecederam revela a profundidade dos desafios vividos por aqueles responsáveis por criá-lo, como veremos. Esses debates não serão expostos exaustivamente aqui, por fugir

101 Título 8º "Das Disposições Geraes, e Garantias dos Direitos Civis, e Politicos dos Cidadãos Brazileiros. Art. 179. A inviolabilidade dos Direitos Civis, e Políticos dos Cidadãos Brazileiros, que tem por base a liberdade, a segurança individual, e a propriedade, é garantida pela Constituição do Imperio, pela maneira seguinte. (...) XVIII. Organizar-se-há quanto antes um Código Civil, e Criminal, fundado nas solidas bases da Justiça, e Equidade. 
do escopo da presente pesquisa a investigação de todos os aspectos que precisaram ser decididos, mas faremos um relato panorâmico deles, para então nos aprofundarmos na participação que Clemente Pereira teve.

\section{$* * *$}

Em 12 de maio de 1826, uma semana após a instalação da Assembleia, o Deputado Silva Maia mandou à mesa uma indicação para que a comissão de legislação fosse convidada a informar à Câmara "as medidas que se devem tomar para a organização dos códigos civil e criminal, e isto com urgência"102. Na mesma sessão o deputado Pires Ferreira propõe que "se decrete um premio a quem dentro do espaço de dois anos apresentar o melhor projeto de código" ${ }^{\text {"103; }}$; instado a especificar qual - o deputado Cruz lembra que "devem haver pelo menos cinco ou seis; há o civil, criminal, marítimo, mercantil, rural, etc" - Pires Ferreira esclarece estar falando "do código em geral”.

$\mathrm{Na}$ sessão seguinte acontece a segunda leitura das indicações mencionadas ${ }^{104}$, que são remetidas à comissão de legislação, responsável pela matéria, e na ocasião um deputado aproveita para informar que - conforme noticiado pela imprensa fluminense o Barão de Cairu apresentara um projeto de Código mercantil, podendo ser que o mesmo tivesse "principiado algum projeto do código civil ou criminal", razão pela qual sugeria que se lhe oferecesse um prêmio se elaborasse tais códigos dentro de um determinado prazo. Como se verá, a expectativa de que a concepção do código pudesse vir de fora do Parlamento não era de poucos.

Mas a primeira proposta não tardou a surgir, antes mesmo que a Comissão oferecesse as solicitadas instruções. Um mês depois das indicações, na sessão de 03 de junho de 1826, José Clemente Pereira apresentou o que chamou de "bases para a elaboração de um Código Criminal”.

\footnotetext{
${ }^{102}$ APB, 12 de maio de 1826, p 58 e 59.

${ }^{103}$ APB, 12 de maio de 1826, p. 60.

${ }^{104}$ Formalidade exigida para todas as iniciativas dos deputados, desde que não consideradas urgentes, caráter atribuído a algumas matérias mediante deliberação dos deputados nesse sentido.
} 
Segundo ele, "sendo ordenações imensas e informes, que se dizem em vigor, são inteiramente inaplicáveis às nossas circunstâncias", resultando disso os males para a administração da justiça.

Para resolver o problema, apresentava as bases do futuro código, para que as mesmas fossem discutidas e eventualmente modificadas. Com 45 artigos, a proposta tratava apenas dos crimes e das penas, apesar do primeiro artigo prometer um livro segundo que traria a ordem do processo criminal, mas o deputado manifestava a intenção de utilizar as bases - se aprovadas - para "prosseguir no seu plano com mais segurança" e em breve apresentar o projeto completo ${ }^{105}$.

Tais bases ${ }^{106}$ estavam divididas em dois títulos. O primeiro, "Dos crimes em geral e seus autores", com onze artigos, trazia a definição de crime, de contravenção e de tentativa. Definia a figura do cúmplice e o rol de inimputáveis. Estabelecia a regra da anterioridade da lei e afirmava serem os crimes personalíssimos. Previa a compensação das perdas e danos (não dos crimes em si) e mencionava as circunstâncias agravantes e atenuantes, "a serem definidas por lei”. O segundo título, "Das penas", iniciava-se por onze dispositivos gerais, classificando as penas como difamatórias e aflitivas, instituindo três graus de imputação (mínimo, médio e máximo), a regra da reincidência e a garantia de não cumulação de duas penas corporais, exceto para os escravos. Em seguida vinham os 23 artigos que instituíam as penas possíveis: de morte, desnaturalização, trabalhos públicos, prisão, degredo, suspensão de direitos políticos e multa.

Na sessão de 09 de junho o projeto foi lido e julgado objeto de deliberação, sendo por isso remetido à Comissão de legislação, justiça civil e criminal $^{107}$.

Dois meses depois, na sessão de 01 de agosto, a Comissão apresentou seu parecer sobre a indicação dos Deputados Pires Ferreira e Maia, trazendo as instruções para a elaboração dos necessários códigos ${ }^{108}$. Afirma que o "objeto de maio importância, e que mais contribui para a felicidade dos povos, é um código completo de sua legislação, que

\footnotetext{
105 APB, 03 de junho de 1826, p. 15.

${ }^{106}$ Ver Anexo 01.

${ }^{107}$ APB, 09 de junho, p. 84.

${ }^{108}$ APB, 01 de agosto de 1826 , p. 16.
} 
contenha todos os direitos e obrigações nos diversos estados e relações sociais". Mas reconhece quanta "dificuldade, porém, seja fazer-se um código tanto civil como criminal completo em todas as suas partes, abrangendo todas as relações assim internas quanto externas, assim públicas como particulares”, e para ilustrar essas dificuldades, já enfrentadas por outros, menciona os escritos de Jeremias Bentham e Vicente José Ferreira Cardoso.

A possibilidade de um código geral é interessante. Como veremos a seguir de maneira mais detalhada o Código de 1830 foi elaborado em uma época chave para a consolidação da autonomia do direito criminal. Queiroz, analisando a questão, conclui que apesar de muitos deputados manifestarem uma clareza em relação à autonomia do ilícito criminal, alguns utilizavam um vocabulário de transição, como se pode ver nas falas acima. A criação de um código exclusivamente criminal não foi, no entanto, fruto da prevalência de um ideário, mas de um pragmatismo que unia os deputados em torno da necessidade de uma reformulação do aparato punitivo do Estado. De fato as constantes falas sobre a necessidade do Código, os brados de censura à ordenação então vigente e a rapidez com que um diploma dessa importância foi criado confirmam essa conclusão; de que apesar das divergências estavam todos unidos em torno da "estratégia de pacificação social por meio da legislação repressiva".

Vê-se assim que, ao menos no que tange à comissão, não se espera "um código em geral", como mencionara o Dep. Pires Ferreira ao fazer sua indicação, mas diplomas separados. E assim o parecer passa então a fornecer as instruções para a elaboração de um código civil e criminal, além de mencionar que "deve, igualmente haver um código comercial, ou seja, separado ou compreendido no mesmo código civil, que tenha por base os mesmos princípios (...)", e que, além destes, "deve também haver o código penal militar de terra e marinha".

O parecer traz então instruções para o código civil ${ }^{109}$ e em seguida para o criminal: “deve ser dividido em duas partes, a primeira conterá o código penal, e a segunda o

\footnotetext{
109 "O código civil brasileiro deve ser dividido em duas partes, contendo uma o código das matérias civis propriamente ditas, e outra o código do processo civil, ambos deverão compreender um sistema luminoso da jurisprudência civil acomodada aos progressos que esta ciência tem feito nas outras nações, às circunstâncias particulares, tanto físicas quanto orais da nação brasileira, conformando-se com a constituição politica do império e observadas as leis de método, precisão e clareza".
} 
código de processo criminal: neste ou em outro código separado, devem ser compreendidas as meras contravenções de polícia, suas penas ou multas, e forma verbal e sumária de processar". Mesmo sucintas as orientações são relevantes: a divisão entre matéria criminal e matéria processual já adota uma forma de conceber a disciplina que se consolidou no final do século XVIII (ou seja, era relativamente recente àquele tempo, como veremos a seguir) e a menção às contravenções de polícia de forma separada, as quais deveriam seguir um rito processual diferente ("forma verbal e sumária de processar") também representa uma escolha entre outras possíveis.

Além das instruções, o parecer entra na questão de como estes códigos serão produzidos. Seguindo a ideia já manifestada pelos deputados nas indicações de maio, recomenda que "a câmara convide os sábios jurisconsultos a empreender este árduo trabalho", e para estimulá-los a tanto deve o Parlamento se valer de "todos aqueles meios que podem excitar o gênio, como distinções honoríficas, estampando-se o nome do autor do código que merecer a preferencia concedendo-lhe o uso de uma medalha de ouro, com legenda, que exprima o reconhecimento e gratidão do Brasil”.

A forma de seleção do código que merecerá tais honrarias é relativamente complexa. Além de envolver Câmara e Senado prevê que, depois de escolhido o vencedor, os projetos finalistas e respectivos pareceres seriam publicados e "remetidos aos tribunais de justiça do império, aos advogados e sábios da nação" para que apresentassem suas sugestões no prazo de seis meses - quase uma consulta pública, para usar um termo atual - e só após o recebimento dessas opiniões é que a câmara os discutiria como projeto de lei ${ }^{110}$.

Em seguida a mesma comissão apresentou o parecer "ao projeto de lei do ilustre Deputado José Clemente Pereira, sobre a divisão do código criminal (...) e os princípios que devem ser reconhecidos como bases para o desenvolvimento dos delitos e das penas, e da ordem do processo criminal" - as bases apresentadas em 03 de junho. A comissão reconhecia os artigos da proposta como "fundados em justiça e equidade, sólidas bases que devem ter os códigos, conforme o $§ 18$ do artigo 179 da Constituição".

\footnotetext{
${ }^{110}$ Como veremos a matéria foi muito debatida, mas não da forma proposta pela comissão nesse parecer.
} 
Sobre os artigos da proposta, continua o parecer, pode "o mesmo autor do projeto ou qualquer" elaborar o código criminal, mas a comissão decide que eles não devem "vincular os jurisconsultos e sábios que, convidados pela assembleia, queiram concorrer á honra de apresentar um código criminal". Isso porque estes candidatos, mesmo "tomando as mesmas bases de justiça e equidade", podem "seguir um diverso sistema que abranja todas as partes da jurisprudência criminal e guardar outra ordem na dedução dos delitos e das penas e forma do processo". Agir diferente, ou seja, vincular as futuras propostas às bases apresentadas pelo deputado, seria "tolher o gênio e obstar que a nação possa conseguir o melhor código", nos dizeres da comissão.

Ambos os pareceres têm sua discussão adiada para 17 de agosto ${ }^{111}$, a começar pelo projeto de bases de Clemente Pereira. Trava-se uma relativamente longa discussão sobre o assunto, envolvendo principalmente o membro da comissão responsável pelo parecer, o deputado Cruz Ferreira ${ }^{112}$, e os deputados Bernardo Pereira de Vasconcelos e Lino Coutinho. Vasconcelos não se conforma com os termos do dito parecer, pois dele não se pode concluir a vontade de seus redatores. Para ele não é compatível, de um lado, afirmar que "o projeto do Sr. Clemente Pereira está bem feito, e seu plano muito bem traçado", e por outro, determinar "que este projeto e este plano não devem obrigar, nem servir de regra aos que empreendem organizar um projeto de código criminal". Por isso pede que o parecer retorne à comissão para que esta cumpra sua tarefa, conforme o regimento: “aprovar o projeto puramente, ou propor-lhe emendas". É apoiado por Lino Coutinho, que também critica duramente a comissão.

Cruz Ferreira defende a posição da comissão; esclarece que não obstante os méritos do projeto, seus membros não julgaram conveniente "ligar estritamente a este plano quaisquer empreendedores, que se proponham a redigir quaisquer projetos de código criminal, e oferece-lo à Câmara", ou seja, as bases não são desaprovadas, mas não devem ser adotadas como modelo a ser seguido. Como se pode ver para a comissão não há incompatibilidade entre os termos, mas os deputados, e principalmente Vasconcelos,

\footnotetext{
111 APB, 17 de agosto, p. 172.

112 José da Cruz Ferreira: natural do Rio de Janeiro, magistrado e deputado geral na $1^{\mathrm{a}}$ legislatura (18261829).
} 
anseiam por entender melhor que efeito esse juízo de aprovação das bases tem sobre os futuros trabalhos.

O juízo da comissão parece mesmo reticente. Se bases de Clemente Pereira eram boas, por que não adotá-las? Porque incompletas? Por outro lado, se não eram úteis, qual o problema em reprová-las? Desprestigiar o autor? Parece prevalecer a crença de que mesmo sendo boas esperava-se que os gênios da nação pudessem produzir melhores coisas ou, produzindo coisas equivalentes, que a depuração do debate entre vários projetos resultaria num projeto melhor. Essa hipótese se funda na proposta de concurso, de formato tão complexo que mostra o quanto estes homens (ao menos a comissão) achavam mais adequado, diante da grandiosidade da tarefa, uma forma de elaboração mais ampla.

É o próprio Clemente Pereira quem interfere na discussão com o intuito de elucidála: sugere que antes de discutir seu projeto é preciso discutir o outro parecer, sobre as instruções. Segundo ele, o futuro de seu projeto depende do julgamento da Câmara sobre aquelas instruções, pois "se a câmara admitir o meio lembrado nas indicações talvez não possa vir a ter lugar a minha proposta". Alguns deputados afirmavam que a comissão, não aceitando como modelo as bases, deveria ter elaborado ela mesma um projeto, diante do que Clemente Pereira afirmava ter sido impossível ao grupo fazer isso sem antes conhecer a opinião dos deputados acerca das instruções.

De fato: no parecer para o qual Clemente Pereira pede prioridade, a comissão propunha uma espécie de grande concurso para a elaboração do código; se os deputados aprovassem essa ideia, ficaria prejudicada a doção do projeto de Clemente Pereira, independente de seus méritos, afinal parecia no mínimo incoerente chamar os "sábios jurisconsultos" a exercerem seu gênio impondo-lhes já um modelo. Note-se que as bases de Clemente Pereira não dispunham apenas de princípios, de modo que se pudesse encará-las como uma grande moldura; apesar de incompleto o texto das bases trazia algumas definições importantes, como um rol de penas, assunto que, como se verá adiante, será bastante controverso.

Seguindo essa sugestão, os deputados passam a discutir as instruções da comissão e sua proposta de procedimento. Vasconcelos ainda insiste em seu incomodo com a 
questão das bases, querendo saber se o projeto de Clemente Pereira vale ou não vale como plano, mas suspende o assunto em função da decisão dos demais.

Cruz Ferreira então afirma que a comissão elaborou sim um projeto de código - que não pretendia revelar antes da analise das instruções, mas decidira revelar o fato diante da acusação de omissão feita por alguns - e em resposta os colegas pedem que se passe a ele, pois não entendem "essa metafísica nova, essa razão sublime, porque não se pode discutir o projeto, sem se aprovarem as bases propostas pela comissão", e que assim proceder é trabalho dobrado.

Diante da informação de existência de um projeto da comissão decidem que o parecer volte à origem e as discussões são novamente adiadas.

O grau de detalhamento escolhido para expor as discussões acima se justifica pela intenção desse trabalho de expor as dificuldades e dilemas envolvidos, para além de seus resultados. Mais que investigar as origens do nosso código criminal e sua relação com a cultura jurídica de então - questões sobre as quais trataremos de maneira não aprofundada - essa pesquisa quer ressaltar o contexto de profundas mudanças colocadas para aqueles que se viam no papel de determinar como seria a ordem jurídica brasileira. Ao jovem parlamento da jovem nação - lembremos que muitos desses homens tinham pouca ou nenhuma experiência na atividade parlamentar, apesar da experiência em outros cargos e desenvoltura na arte da jurisprudência - cabia a monumental tarefa de criar uma legislação à altura das luzes dos novos tempos, que serviria a todas as diferentes partes do território nacional, com suas conhecidas diferenças e particularidades. Mais do que se adequar a essas diferentes partes, essa legislação é que se lhes daria unidade, sendo essa uma das funções políticas que o ordenamento deveria desempenhar.

E eles tinham consciência dessa dificuldade, ligadas às novidades vividas pelo advento da nova nação, mas também ao concomitante e então recente processo de codificação, no qual o mundo todo - ou boa parte dele - estava envolvido. Os registros dos debates parlamentares são testemunhos vivos do quanto o surgimento dos modernos códigos significou não apenas reunião sistematizada da legislação - o que alguns soberanos vinham fazendo há um século - mas de criação normativa e, numa análise 
mais profunda, de consolidação de uma nova concepção do direito (Lopes, 2003 e Slemian, 2008).

Em 04 de maio de 1827 Bernardo Pereira de Vasconcelos apresenta outro projeto para o Código Criminal (Anexo 03). Consta da ata a seguinte indicação "O Sr. Vasconcelos mandou à mesa um projeto de código criminal, que ficou para se the dar destino" ${ }^{\prime 13}$. No dia seguinte decidiu-se criar uma comissão especial para análise do Código $^{114}$; cuja leitura foi dispensada e sua discussão, adiada ${ }^{115}$.

Em 16 de maio de 1827 é Clemente Pereira quem se manifesta sobre o assunto, e apresenta um novo projeto:

"Sr. presidente, na sessão passada tive a honra de oferecer à consideração desta augusta câmara as bases para o projeto de código criminal. (...). Bem conheci o perigo que havia de entrar em grandes trabalhos sem ter bases que me certificassem o modo de pensar da câmara, todavia pus mão ao trabalho, e tenho a honra de apresentar hoje a esta câmara (e remeteu) a primeira parte do projeto criminal, isto é, o livro primeiro que trata dos crimes e das penas, e não ultimei o trabalho do processo, que deve fazer o objeto do livro segundo do código criminal (...) Demais o processo sobre que deve marchar a máquina do código dos crimes e penas, sobre o merecimento deste mesmo projeto e sistema seguido nele, decidirá a câmara; e se ele merecer a sua consideração, terei a honra de apresentar depois a segunda parte em harmonia com o projeto que trata dos crimes e das penas. $^{116,}$

O presidente então determinou que se seguisse o mesmo procedimento do projeto de Vasconcelos: dispensa das duas leituras e remessa à comissão especial para a revisão de ambos. O conteúdo desse projeto não consta das atas do parlamento, e na verdade

\footnotetext{
${ }_{113}$ APB, 04 de maio de 1827, p. 16.

${ }^{114}$ Consta que Vasconcelos, Clemente Pereira e Lino Coutinho concordaram com a criação da comissão.

115 APB, 05 de maio de 1827 , p. 18.

${ }^{116}$ APB, 16 de maio de 1827 , p. 97.
} 
nunca chegou a ser discutido, pois como se sabe, a Câmara escolheu se basear no projeto de Vasconcelos ${ }^{117}$.

\subsection{O projeto de Clemente Pereira}

A seguir faremos uma análise da organização do segundo projeto de código apresentado por Clemente Pereira, procurando situá-lo em relação a algumas referências: o projeto de Bernardo Pereira de Vasconcelos e o Código de $1830^{118}$. Com isso temos por objetivo lançar luz sobre a relação do documento com a concepção jurídica então em voga para a matéria. Adotaremos três questões levantadas por Queiroz para análise do Código de 1830 (2009, p. 233 e ss) para avaliar o projeto de Clemente Pereira: sua posição em relação à afirmação do direito penal contemporâneo; a divisão metodológica em parte geral e parte especial e a autonomia do direito penal em relação ao processo penal.

Não é nosso objetivo analisar todos os artigos do código dessa perspectiva, mas apenas sua sistematização e organização, análise relevante tendo em vista o fato de que a forma de conceber o direito criminal estava mudando, e essa concepção se expressava na distribuição e organização de seu conteúdo, tanto na doutrina quanto nos códigos ${ }^{119}$.

Também não pretendemos elaborar juízos sobre as origens desse documento, ou seja, investigar as influências de outras legislações, projetos ou ideários. Para tanto seria

\footnotetext{
${ }^{117}$ A historiografia consultada, ao comentar essa escolha, faz menção à iniciativa de Clemente Pereira se referindo às bases apresentadas em junho de 1826, raramente ao projeto de maio de 1827. Só encontramos referência em dois autores, Carvalho (2002, p. 463), e Hungria (1977), que informam a data de apresentação de um novo projeto por Clemente Pereira e comentam o desenvolvimento dos debates levando-o em consideração. Nenhum dos dois autores trata do conteúdo do projeto, mas foi a partir destas referências que buscamos o conteúdo da iniciativa; a localização do documento e o acesso ao seu conteúdo só foi possível graças ao contato que travei com a pesquisa da historiadora Monica Duarte Dantas, cujo trabalho é largamente incorporado aqui. Tal contato se deu por intermédio de sua orientanda Vivian Chieregati Costa, que além de compartilhar comigo reflexões sobre nossas pesquisas gentilmente me cedeu o microfilme com a íntegra do projeto.

${ }^{118}$ Cabe aqui lembrar que, apesar de parte da historiografia enxergar grande continuidade entre o projeto de Vasconcelos e o código promulgado, há diferenças importantíssimas (ver Dantas, no prelo). Sobre as influências de outros códigos na elaboração do projeto de Vasconcelos e no Código aprovado, ver Dantas (idem) e Bravo Lira (2004).

${ }^{119}$ Uma ressalva importante de Queiroz (2009), de que a organização metodológica e a divisão dos códigos modernos em parte geral e especial são produtos de uma ideologia então em ascensão e consolidação: "a divisão dos códigos é, juntamente com a do direito penal como objeto teórico (e não antes dela), produto de uma certa concepção de racionalidade como instrumento intelectual de organização de conhecimento e obtenção de verdades confiáveis”. p. 241.
} 
necessário um mergulho na história do direito penal que cabe aqui realizar, mas que tem sido empreendido por competentes pesquisadores que vêm ampliando e revisando a historiografia da questão ${ }^{120}$.

O projeto que corresponde à parte primeira do que viria a ser o código, traz trinta $\mathrm{e}$ três títulos (ver Anexo 02), que tratam "dos crimes e das penas". Inicia-se pelo que seria a parte geral, sem que se expresse tal divisão, composta por dois títulos: título I, "Dos crimes em geral, e seus autores", que abriga dois capítulos, que tratam (1) dos crimes e (2) dos autores dos crimes. Em seguida vem o título II, "das penas", composto por cinco capítulos, sobre (1) das penas em geral; (2) da pena de morte; (3) da pena de trabalhos públicos; (4) da pena de prisão e (5) da pena de multa ${ }^{121}$.

$\mathrm{Ou}$ seja, existe uma divisão entre parte geral e parte especial, mesmo que subjacente. Em relação ao projeto de Vasconcelos e ao Código de 1830 há uma aproximação, pois eles também se dividem assim, ainda que de maneira mais clara e sistematizada. Clemente Pereira era claramente um defensor da maneira "principiológica" de encarar o direito: além e ter apresentado na Câmara, antes de um código completo, suas bases ${ }^{122}$, ele incorporou essa forma em seu projeto, ainda que de maneira menos sofisticada que seu "concorrente" (o projeto de Vasconcelos) e nos debates sobre essa questão na Câmara, apoiou a posição de seu inimigo ${ }^{123}$.

Em seguida vem o que seria a parte especial, composta por 30 títulos, que correspondem ora a crimes, ora a conjuntos de crimes. Não há uma divisão expressa entre crimes públicos ou privados, mas os primeiros títulos são os crimes que o código criminal qualificou como públicos: (III) “crimes contra a religião do Império", (IV) "das injúrias feitas ao Imperador", (V) "dos crimes contra as garantias da constituição política do Império”, (VI) “dos crimes contra a segurança externa do Império”, (VII)

\footnotetext{
${ }^{120}$ Dantas (no prelo), Slemian (2006b), Queiroz (2009).

${ }^{121}$ O Título II, "das penas", aparece de forma um pouco distinta em sua iniciativa anterior: nas bases de 1826 o titulo trazia, além das previsões gerais, seis tipos de pena: morte, desnaturalização, trabalhos públicos, degredo, suspensão dos direitos políticos e multa. No projeto de 1827 há quatros tipos de pena: morte, trabalhos públicos, prisão e multa.

${ }^{122}$ Ainda que as bases não se resumissem a princípios.

${ }^{123}$ Vasconcelos se opôs à criação de uma lei especial para a responsabilidade dos ministros e conselheiros de Estado, defendendo que tal matéria deveria constar no Código. Era contra a criação e leis sui generis que não estivessem subordinadas aos princípios que seriam estabelecidos no Código. A questão é reproduzida por Machado Neto (1977) e Queiroz (2009, p. 244). Foram vencidos e a lei de responsabilidade foi criada em outubro de 1827, enquanto o Código só foi promulgado em 1830.
} 
"dos crimes contra a segurança interna do Império", (IX) "dos crimes de resistência pública", (X) "dos crimes de desobediência aos mandados das autoridades constituídas"; (XI) "da falta de respeito devido aos que exercem o poder"; (XIII) "das prevaricações, abusos e omissões dos empregados públicos", subdividido em cinco capítulos, intitulados "do crime de peculato", "do crime de peita", "do crime de concussão", "da falta de exacção dos empregados públicos no cumprimento de seus deveres", "do excesso de autoridade"; (XIV) "do crime de moeda falsa", (XV) "do crime de falsidade", (XVI) "do crime de perjúrio" e (XXVIII) "dos crimes contra o comércio público", subdividido em dois capítulos: "dos que falsificam mercadorias para vender" e "dos que usam de pesos, medidas, balanças falsas ou falsificadas".

Vêm em seguida os que seriam os crimes particulares, na classificação do código criminal: (XVII) "do crime de calúnia”, (XVIII) “do crime de injúria”, (XIX) “dos crimes de sodomia, bestialidade e molicie", (XX) "do crime de bigamia", (XXI) "do crime de adultério"; (XXII) "do crime de rapto e estupro"; (XXIII) "do crime de lenocínio", (XXIV) "do crime de homicídio", (XXV) “do crime de ferimentos”, (XXVI) "do crime de furto"; (XXVII) "do crime de quebra dolosa".

Ao longo do texto encontramos, ainda, as contravenções de polícia; algumas estão reunidas em um título exclusivo: (XXXII) "das contravenções de polícia e boa ordem pública”, mas há ao longo do projeto títulos que correspondem a delitos deste tipo, a adotar-se o critério do código criminal: (VIII) "das sociedades secretas", (XII) "dos crimes contra a tranquilidade pública", subdivido em cinco capítulos denominados "dos pasquins", "do uso de armas proibidas", "do crime de desafio", "do crime de tumulto" e "do crime de assuada"; (XXIX) "dos que usam de nomes, títulos, uniformes, condecorações ou distintivos indevidos" e (XXXI) "dos vadios, mendigos e jogadores", subdivido em três capítulos para cada um desses itens.

Chama a atenção que o projeto comece o que seria sua parte especial pelos delitos públicos, trate dos particulares e termine com um título sobre as contravenções; essa foi a ordem adotada pelo código criminal e 1830; o projeto de Vasconcelos continha o inverso: depois da parte geral vinham os crimes policiais, em seguida os particulares e por último os públicos. A questão não é irrelevante, tendo em vista que um dos elementos presentes na nova forma de codificação era a ordenação por gravidade; não 
há elementos que nos permitam concluir sobre essa questão, mas pode significar que Clemente Pereira e a concepção que prevaleceu no Código de alguma forma privilegiassem a ordem pública sobre a privada, enquanto o Vasconcelos liberal pensasse diferente.

Como já mencionado, a sistemática desses títulos não é homogênea; alguns são agrupados pelo bem jurídico a ser protegido, como é o caso, por exemplo, dos (III) crimes contra a religião do Império, (VI) dos crimes contra a segurança interna do Império ou (XII) os crimes contra a tranquilidade pública, entre outros. Em oposição, muitos títulos que não representam o mesmo grau de abstração, correspondendo a crimes, que por sua vez não são agrupados em nenhum conjunto maior. Alguns exemplos: (XIV) crime de moeda falsa; (XXIV) homicídio, (XXVI) furto, etc. É verdade que crimes que o código de 1830 une sob o mesmo título estão, no projeto de Clemente Pereira, próximos, mas nem sempre essa unidade é completa.

Em suma: o bem jurídico protegido é usado de maneira parcial como critério organizador; ele serve para constituir alguns títulos, mas não todos; e mesmo quando olhamos para a proximidade dos crimes em sua disposição (a economia do texto) abrindo mão do agrupamento expresso, há escolhas difíceis de interpretar: pode ser que tenha faltado, como parece, rigor ao autor, mas poderia ser também que ele entendesse o caráter dos crimes de maneira diversa que outros o fizeram. Casos extremos são as contravenções de polícia: a Clemente Pereira não parece ter escapado quais eram, no seu código, as contravenções de policia ou crimes policiais, pois ele não as chama de crimes; se isso é verdade, porque não as colocou todas juntas e mais, sob o mesmo título?

Sobre o terceiro aspecto, o divisão do direito penal e direito processual, o projeto de Clemente Pereira parte de uma separação dessas matérias ${ }^{124}$; ainda que não tenha

\footnotetext{
${ }^{124}$ Não se pode dizer que a configuração fosse a mesma do direito penal contemporâneo, que separa totalmente as disciplinas do direito penal e direito processual, tendo cada um deles seus princípios e abrigados em códigos separados. Queiroz (2009) afirma tal ponto se baseando no fato de que Clemente Pereira inclui, no "código criminal", um livro sobre os crimes e as penas e outro sobre o processo. Aventa que ele teria assim procedido por "ter tomado por modelo outros códigos europeus em que isso se dava, quanto pela necessidade prática de se organizar com urgência o sistema judicial brasileiro, que àquela altura ainda era em grande parte regido pela legislação portuguesa". Vasconcelos apresentaria em seu discurso a mesma ambiguidade (p. 246 e ss).
} 
apresentado a parte do processo porque não lhe fora possível elaborá-la, como avisa em seu discurso. O preâmbulo das bases já trazia tal configuração.

Art. $1^{o}$ O código criminal do império do Brasil será dividido em dois livros: o primeiro tratará dos crimes e das penas, e o segundo conterá a ordem do processo criminal.

Art. $2^{o}$ Ficam desde já reconhecidos como bases os seguintes princípios, que formarão os primeiros dois títulos do livro primeiro do sobredito código ${ }^{125}$.

Não se pode analisar melhor o assunto porque Clemente Pereira não a elaborou, mas pelo que fez pode-se afirmar que sua posição era semelhante a de Vasconcelos. Esse também principia seu projeto de código em torno de uma primeira parte, "dos crimes e das penas" ${ }^{126}$, e em discurso de 05 de maio de 1827, dia seguinte à apresentação de seu projeto, ele menciona outras duas partes, uma segunda sobre "matérias judiciais" e uma parte terceira "da ordem do processo"127, todas reunidas no Código Criminal. As mesmas dificuldades de analise se colocam, porque não se conhece a parte do projeto de Vasconcelos que traria a matéria processual.

O Código de 1830 como se sabe se restringiu à matéria penal - a disciplina processual só veio dois anos depois. A parte primeira "dos crimes e das penas" é a parte geral do Código, mesmo sem esse nome. As partes seguintes compõe a parte especial: segunda é denominada "dos crimes públicos, a terceira "dos crimes particulares", a quarta "dos crimes policiais".

Em resumo, os projetos de Clemente Pereira e Vasconcelos tinham configuração semelhante, ainda que a julgar pelo modelo de sistematização em voga e que foi adotado no Código Criminal, o de Vasconcelos fosse mais bem elaborado.

\footnotetext{
${ }^{125}$ APB, 03 de junho de 1826, p. 15.

${ }^{126}$ Projeto apresentado em 04 de maio de 1827. Não consta nos anais da Câmara.

${ }^{127}$ APB, 05 de maio de 1827, p. 23.
} 
Há muitos outros aspectos interessantes no projeto do ponto de vista da sua sistematização, com detalhes, análises mais profundas e mais exemplos dos elementos para os quais chamamos a atenção acima. Muito rico, se mostrará, também, uma investigação do se conteúdo, artigo por artigo, para julgar de que maneira os crimes para Clemente Pereira se deveriam definir, em oposição ao projeto de Vasconcelos e em comparação às fontes das quais ele provavelmente se serviu. Com isso se poderá aprofundar o conhecimento sobre a visão de mundo do magistrado fluminense no que diz respeito ao direito penal, nas duas vertentes que essa disciplina tinha: a do desafio político, de centralização do poder de punir do estado, quanto da vertente garantista: a defesa do cidadão diante do arbítrio judicial. Outros elementos da trajetória de Clemente Pereira coletados e costurados nesse trabalho nos permitem adivinhar que a cotização de seu projeto com seus interesses políticos e ideário jurídico é profícua: como pudemos ver, ao mesmo tempo em que Clemente Pereira esteve no campo de batalha liberal, esteve também no comando dos exércitos do poder (metafórica e literalmente falando).

Em segundo lugar, o aprofundamento da investigação apenas iniciada aqui poderá mostrar em que medida o projeto de lei de Clemente Pereira contribuiu para os debates e a configuração final do Código de 1830. Há motivos para pensar que a questão não está bem colocada, pois a historiografia específica do tema não leva em conta a contribuição mais significativa dele, restringindo-se às bases, o que leva a pensar que essa contribuição não pode ter sido muita, tendo em vista a patente concisão desse documento.

Só essa análise profunda e detalhada do conteúdo poderá indicar o lugar a lhe ser dado na formulação do nosso direito penal; a questão é ainda dificultada por outro fator: as atas dos debates parlamentares atestam, ainda que com eufemismos, que o projeto de Clemente Pereira foi preterido; também é verdade que ele se alienou completamente dos debates, ainda que não pareça justo crer que por desinteresse; afinal estamos falando de um deputado que elaborou, em um ano, duas iniciativas para matéria, sendo uma delas um texto completo para a parte penal (ou que ao menos se pretendia completo); deputado esse que, quando apresentou tais projetos, já era um magistrado experiente. 
Esse "desaparecimento" de Clemente Pereira pode ser explicado também pelo contexto político: o período de 1826 a 1830 foi extremamente conturbado para ele. Um ano depois de apresentar seu projeto ele se torna ministro e será combatido pelos liberais, durante e após sua administração. Estes se tornam maioria em 1829, auge dos debates do Código Criminal, quando o governo liderado por Clemente pereira está sob fogo cerrado (acusação do Ministro da Guerra); é desse ano o parecer da comissão que afirma que o projeto de Vasconcelos seria tomado como base. O trâmite do projeto continua no ano de 1830, quando tentam impedir Clemente Pereira de tomar posse; é de se supor que mesmo depois de sua posse o ambiente não fosse muito favorável para a defesa de seus pontos os de vista, tanto é que, mesmo presente, ele não se manifesta nas sessões dos meses de setembro e outubro de 1830, quando questões importantes são definidas e votadas, como a pena de morte e galés. Os protagonistas dos debates são os liberais e na composição das comissões vemos os nomes dos combatentes inveterados de Clemente Pereira: Vasconcelos e Limpo de Abreu, entre outros.

A adotar como régua a concepção de código em voga na época como aqui descrito, o projeto de Clemente Pereira está mais distante do ideal do que de Vasconcelos, mas ele se situa nessa tradição. Há incoerências na lógica interna de sua organização, mas o projeto de Vasconcelos também tinha suas incoerências. O trabalho de Dantas (no prelo) aprofunda a investigação das diferenças entre ele e o Código aprovado e busca a fonte dessas mudanças, já representando inovação na historiografia que trata das influencias presentes no nosso ordenamento. Talvez essa análise mais profunda do projeto de Clemente Pereira possa recolocá-lo nesse rol. Alguns elementos levantados na presente apontam essa hipótese: o fato de que o projeto traz, ainda que com organização diferente, as mesmas matérias que o projeto de Vasconcelos e o Código de 1830 e que muitos dos principais títulos se assemelhavam, fazendo crer que a fonte de Clemente Pereira tenha sido a mesma de Vasconcelos - qualquer que seja ela. 


\section{CAPÍTULO 3 \\ O CÓDIGO COMERCIAL}

\subsection{O comércio no Brasil}

Às vésperas da apresentação do projeto do Código Comercial, na década de 30, o comércio no Brasil formava um quadro bastante complexo. A praça mercantil do Rio de Janeiro se tornara o centro econômico e político do Sudeste brasileiro, configurando-se como "ponto de encontro do escravismo colonial com as produções comerciais de abastecimento interno", onde no início do século XIX a atividade mercantil sustenta a preeminência de uma elite de negociantes em detrimento da aristocracia fundiárioescravista (Fragoso, 1998, p. 303, passim).

Esses negociantes não só dominavam vários setores do comércio interno e externo mas também faziam garantiam a liquidez do sistema, atuando como financistas, uma vez que inexistiam instituições de crédito de peso. Isso fazia com que "a atividade financeira se confundisse com o comércio, ou, ainda, que tal atividade se fizesse por uma cadeia de endividamentos".

A própria independência teria resultado de imbricados interesses em luta num contexto de mudanças econômicas que já se esboçavam desde antes da transferência da Corte em 1808 (Oliveira, 1999). Trata-se do processo de mercantilização da terra e da mão-de-obra que acontecia não só no Rio de Janeiro como em algumas regiões de Minas Gerais e São Paulo, desde meados do século XVII. Com a reorganização econômica decorrente da decadência da extração do ouro, a terra passa a ser instrumento de obtenção de lucro, e a agricultura passa a ser uma das atividades mais lucrativas da região.

A vinda da família real inaugurará então um período de políticas econômicas contraditórias, em que a intervenção do governo foi a um só tempo protecionista, com o objetivo de manter os privilégios do monopólio comercial que beneficiava Portugal, e liberalizante, pois visando aumentar a produção propiciou o desenvolvimento de atividades econômicas independentes. Todo esse quadro se inseria num contexto 
mundial de gradual extinção das regulamentações do antigo regime e instauração de relações de livre mercado.

Os grupos com diferentes interesses econômicos que surgem na arena política disputam poder e influência. Um destes grupos era composto pelos proprietários de duas regiões o Recôncavo da Guanabara e Campo de Goitacazes, na província do Rio de Janeiro, que produziam para exportação e abastecimento do mercado interno, mas se distinguiam dos tradicionais proprietários de grandes latifúndios e escravos, mas com eles disputavam negócios e poder.

Uma destas disputas se dava em torno dos contratos de arrematação ${ }^{128}$ de cobrança de impostos, negócio extremamente lucrativo por seu volume - houve um grande aumento na criação de impostos entre 1808 e 1821 - e modelo. O processo era controlado pelo Real Erário e Câmaras Municipais, privilegiando-se negociantes atacadistas, famílias poderosas e membros da alta burguesia. Contra isso se insurgiam os proprietários do Recôncavo e Goitacazes, pois não tinham acesso a esses privilégios.

\subsection{A criação do direito comercial nacional}

O comércio sempre fora visto como objeto de direito público (b, 2007, p. 11 e ss.). De acordo com Mello Freire os atos de cada negociante eram privados, mas o comércio propriamente dito, ou seja, a ordem pública na qual se dava esses atos era objeto do direito público, a dar regras, limites e sentido, organizando aqueles atos.

Em 1755 é estabelecida em Portugal a Junta de Comércio, sob os interesses da Coroa de defender o comércio - não dos interesses e lucros dos comerciantes, mas como um serviço a gerar benefício para o reino. Essa corporação passa a fazer parte dos conselhos do rei, relativizando a autonomia corporativa dos comerciantes e integrando a atividade na máquina do governo, o que se refletia em sua composição.

Em 1756 fixam-se os Estatutos da Junta, encarregada do "governo econômico do comércio". Misturavam-se cargos de natureza administrativa e judiciária. Até 1771 o

\footnotetext{
${ }^{128}$ Fragoso também chama a atenção para o fato de que a diversificação das atividades dos negociantes incluir a arrematação de impostos, o que lhes dava vantagem sobre os demais (Fragoso, op. Cit.)
} 
juiz conservador vai acumulando competências e poderes relacionados ao que Lopes chama de "controle para o bom funcionamento do mercado". Mas em 1771 este cargo é extinto e suas atribuições distribuídas.

Até o fim do século XVIII o Brasil não tem, por seu estatuto de domínio, participação direta na gestão do comércio. Funcionam até então as mesas de inspeção, "a meio caminho entre repartições de investigação criminal e polícia econômica" (Lopes, 2007b, p. 17). O quadro começa a mudar em 1808, com a criação da Real Junta de Comércio, Agricultura, Fábricas e Navegação do Estado do Brasil, valendo em primeiro lugar, para o Rio de Janeiro. Nela o juiz conservador, diferentemente de Portugal, acumulará funções até 1810.

Mas esse juízo conservador não indicava autonomia da corporação dos mercadores, mas sua subordinação: os juízes eram juízes letrados e vigorava uma intensa regulamentação, porque os resultados do grande comércio interessavam muito ao Estado, seja pelas suas rendas, seja pela política de alianças com as nações com que se comerciava. Assim, nas primeiras décadas do século XIX o comércio é visto como "um ramo relativamente definido de direito privado, mas no qual não se notava ainda tanto a autonomia dos privados exigida por um ideário liberal” (Lopes, 2007, p.17).

Não havia um tribunal para os assuntos do comércio. A Junta era mais um órgão de consulta e governo. Só o juiz conservador detinha jurisdição voluntária e contenciosa, especialmente para os casos de quebra e havia outros juízes especiais que lidavam com matéria mercantil, mas não de maneira exclusiva. Na primeira instância os casos comerciais estavam sob responsabilidade dos ouvidores do cível, mais tarde (1832) substituídos por juízes de direito e municipais, conforme o caso.

Quanto às fontes: havia a regulação própria das atividades e, desde 1769, a Lei da Boa Razão, que autorizava a aplicação, nos casos de dúvida e lacunas, a legislação estrangeira. Embora não estivesse entre os códigos previstos na Constituição do Império, o Código Comercial foi privilegiado pelos legisladores e deu início à 
construção do arcabouço jurídico civil ${ }^{129}$. Em 1832 uma comissão foi nomeada pela Regência para prepará-lo, composta por Limpo de Abreu ${ }^{130}$, José Antonio Lisboa, Inácio Raton ${ }^{131}$, Guilherme Midosi e Lourenço Westin ${ }^{132}$. Limpo de Abreu deixou a comissão para se dedicar à presidência da Câmara dos Deputados e foi substituído por José Clemente Pereira, a quem apenas um ano antes acusara de crimes na Câmara.

Lembramos que, mesmo exercendo seu mandato como deputado, Clemente Pereira está alijado dos debates na Câmara desde sua acusação, em maio de 1831, até agosto de 1833. Agora vemos que mesmo combatido pelos liberais no Parlamento ele não estava alheio à política. É nomeado pela Regência no mesmo momento em que é absolvido da acusação no Senado.

O projeto da comissão ficou pronto em 1834 e iniciou sua tramitação em 1835 no plenário da Câmara. Nesses anos Clemente Pereira está exercendo o mandato de deputado provincial, mas volta ao Parlamento em 1838.

Em 1843 Clemente Pereira se torna senador pela província do Pará, e três anos depois, em 1846, o projeto de código comercial inicia sua tramitação no Senado. O auge de seu debate em 1848, protagonizado pelo magistrado português, por José Antônio da Silva Maia e Bernardo Pereira de Vasconcelos. Aqui, mais uma vez, Clemente Pereira e Vasconcelos estarão em lados opostos, separados por interesses econômicos diversos o primeiro representando as posições dos comerciantes do Rio de Janeiro, a quem sempre estivera ligado e o segundo, desde que se tornara líder do regresso, os interesses da indústria e da lavoura.

\footnotetext{
129 Talvez pela pressão dos comerciantes das praças mercantis do Império talvez porque o direito comercial fosse considerado mais urgente e menos constitucional (fundamental) para a ordem jurídica (Lopes, 2007, p. 23 e ss.).

${ }^{130}$ Antônio Paulino Limpo de Abreu (1798-1883) era natural de Lisboa. Estudou Direito na Universidade de Coimbra. Regressou ao Brasil em 1820, iniciando sua carreira na magistratura como Juiz de Fora da vila de São João d'El-Rei. Foi Desembargador da Relação da Bahia, deputado pela Província de Minas Gerais por várias legislaturas entre 1826 e 1848 e presidente da mesma Província (1833-5). Em 1842, foi deportado para Portugal em conseqüência da sua participação nos pronunciamentos armados das províncias de São Paulo e Minas Gerais, tendo regressado no ano seguinte. Ocupou várias vezes o cargo de ministro (do Império, da Justiça, dos Estrangeiros e da Marinha), sendo também ministro do Supremo Tribunal de Justiça (1846-8). Foi escolhido senador em 1847. Obteve o título de Visconde de Abaeté (Slemian, 2006, p.159).

${ }^{131}$ Presidente da Companhia Brasileira de Paquetes, diretor da Phenix Fluminense - companhia de seguros - empresário gerente da Companhia de Navegação para Vapores Macahé e Campos, conselheiro do Banco Comercial do Rio de Janeiro (Neves, 2007, p. 193).

132 Substituiu Honório Teixeira, que recusou a nomeação. Lourenço Westin era negociante estabelecido na Corte e cônsul da Suécia (idem).
} 
O projeto defendido por Clemente Pereira criava os tribunais de comércio nos moldes de câmaras especiais, com jurisdição ordinária em certos casos e recursal em outros. Seriam compostos por juízes letrados e leigos, e coexistiriam com os juízos comuns.

Lopes (2007b) analisa e sintetiza as objeções levantadas à proposta, com participação de Vasconcelos em todos os pontos: (1) os custos envolvidos, por demandar a ampliação do aparato judiciário; (2) sua constitucionalidade, uma vez que os juízes introduzidos pela nova instituição não gozariam das garantias constitucionais e seriam eleitos por uma classe de cidadãos, os comerciantes; (3) a dúvida sobre sua imparcialidade, pela possibilidade de cooptação pelos grandes comerciantes, muitos deles estrangeiros. Por último, duas oposições que podemos mais amplas, sendo uma jusfilosófica e outra política: (4) o debate em torno da autonomia do direito mercantil, temendo-se que a dificuldade envolvida em se separar completamente a matéria civil da comercial abrisse as portas para "uma colonização de todo o direito privado pelo direito comercial $^{133}$ " e por fim, (5) a compatibilidade dos tribunais de comércio com o federalismo, posto que a proposta considerava a realidade de apenas parte do Império, as regiões com grandes portos.

A oposição representada pelos dois senadores era, como dissemos, a luta de poderosos interesses econômicos, mas também - e a ale ele costurados - o embate entre v duas visões divergentes sobre a situação do comércio do Brasil à época. De um lado, os combatentes dos tribunais de comércio entendiam que o problema era de confusão legislativa, de incerteza na legislação a ser aplicada. Vasconcelos defendia, inclusive, a simples abolição da jurisdição mercantil, ao invés da criação dos tribunais, que em suma, só trariam privilégios nos julgamentos pela captura do aparelho judiciário.

Já os defensores dos tribunais se insurgiam contra a lentidão a que as causas eram submetidas sob o processo ordinário civil, o que seria solucionado pelo processo simplificado que os tribunais mercantis e juízos comerciais estariam autorizados a aplicar.

\footnotetext{
${ }^{133}$ Lopes (2007b), p. 29.
} 
Em 1850 o projeto foi finalmente aprovado da seguinte maneira ${ }^{134}$ : os tribunais de comércio foram criados para cuidar da jurisdição voluntária, do auxilio ao governo e desenvolvimento do comércio e da jurisdição das falências (quebras); foram instalados na Corte, na Bahia e no Recife. Eram também responsáveis pelo julgamento das matérias comerciais em segunda instância nessas localidades, configurando-se em seções especiais das Relações, composta por três desembargadores (juízes letrados) e dois representantes dos comerciantes (deputados).

As controvérsias mercantis em primeira instância ${ }^{135}$ permaneceram na jurisdição comum, a cargo dos juízes municipais, exceto nas cidades com grande comércio (as mesmas que receberam os tribunais - Corte, na Bahia e no Recife - além de São Luís), em que foram criados juízes especializados para a matéria ${ }^{136}$. Essa não era uma originalidade brasileira, sendo o modelo adotado na França e fundamentado pela doutrina.

Os locais acima citados mostram que foi privilegiado o grande comércio marítimo, onde também se concentravam as atividades financeiras relativas ao crédito e seguros (p. 35). A jurisdição mercantil existia para atender as necessidades dessa atividade, com as especificidades da matéria e a necessidade de julgamento mais célere. Por isso essa localização e configuração, com representantes dos próprios comerciantes, apenas confirmados pelo rei.

Seus defensores argumentavam que a jurisdição especial se justificava em razão da matéria, não da pessoa, portanto não representavam jurisdição privilegiada, forma de justiça típica da sociedade estamental do antigo regime. Sua fundamentação seria técnica, não a do favorecimento. Por outro lado, seus combatentes os viam como órgãos administrativos, não judiciais; o argumento técnico não era suficiente - afinal, ser comerciante não significava conhecer todo o universo do comércio - e permanecia a

\footnotetext{
${ }^{134}$ A Câmara foi dissolvida em 1849, mas logo que reinstalada em 1850 aprovou o projeto da forma como fora emendado pelo Senado.

${ }^{135}$ Os recursos dessas decisões eram julgados pelas Relações respectivas, exceto em matéria de quebra, que independente do local era de responsabilidade dos Tribunais de Comércio.

${ }^{136}$ Houve ainda a criação e juntas de comércio em três províncias, que detinham grandes portos. Esses órgãos detinham funções administrativas de regulação das atividades mercantis, a cargo de uma autoridade local, dois representantes dos comerciantes (deputados). Essas juntas serão estendidas a todas as províncias marítimas do Império.
} 
crítica sobre o potencial domínio dos comerciantes exerceriam - já representada por Vasconcelos durante os debates parlamentares, que temia pelos fazendeiros que se relacionavam com estes grandes comerciantes e que se submetiam a este sistema ${ }^{137}$.

Nesse sentido Lopes conclui que "o Código e seu sistema judiciário não é tanto um artifício do Estado para dominar o comércio, quanto um artifício de certos grupos de comerciantes para dominarem, valendo-se do Estado, todo o comércio" (Lopes 2007b, p. 47). Mais do que isso, através das atribuições dos Tribunais de Comércio os comerciantes tinham um acesso privilegiado ao governo, pois consultavam o Conselho de Estado acerca de projetos de lei e em casos de dúvida na aplicação e interpretação da legislação.

Outro aspecto deste embate é o fato de que estava em disputa "o poder e o prestígio entre uma parte da elite imperial, formada por bacharéis, e outra parte de grande importância, qual seja, os negociantes dos grandes portos, muito especialmente da Corte" (Neves, apud Lopes 2007b, p. 44). Um homem que estava entre esses dois mundos será nomeado o primeiro presidente do Tribunal de Comércio da Corte em 1850: José Clemente Pereira ${ }^{138}$.

\footnotetext{
${ }^{137}$ Os Tribunais de Comércio serão extintos em 1873.

${ }^{138}$ Nomeado em 04 de setembro de 1850, com instalação em 02 de janeiro de 1851.
} 


\section{CAPÍTULO 5 \\ CONCLUSÃO}

José Clemente Pereira viveu em período em que além da consolidação da unidade territorial pós-independência, estava em formação o direito nacional que deveria substituir a legislação portuguesa, agora estranha à nossa ordem política, uma vez que se dera a separação entre Brasil e Portugal.

O Brasil viveu estes desafios em um contexto mundial de monarquias restauradas (acalmados os ventos revolucionários e reorganizada a geopolítica do globo), valorização do direito pátrio, codificação no sentido moderno, centralização dos poderes de legislar e julgar nas mãos do monarca, agora ilustrado, e de alçada da legislação à posição de grande via de reforma da sociedade.

Isso coloca um primeiro aspecto do panorama que quisemos aqui traçar: o de que, dentro de suas particularidades, o Brasil enfrentava questões colocadas para outras nações. A imensa tarefa de criar uma legislação nacional não se dava $a b$ ovo, mas os tempos trazidos pela independência e por todos esses movimentos acima descritos tinham a marca da novidade, o que gerava muitas possibilidades mas também ansiedade, agravada pela percepção da necessidade dessas novas leis para a consolidação das conquistas e para a viabilização da ordem social.

Não nos foi possível analisar de maneira detida muitos dos aspectos envolvidos, como a questão do ensino do direito, ou detalhes dos aspectos sociais e econômicos mais relevantes ou aprofundamentos nos ideários políticos e filosóficos em voga ou em disputa. A escolha da trajetória de Clemente Pereira para tratar de questões importantes do debate jurídico do Império se mostrou extremamente profícua e envolvente. Se por um lado isso comprovou a validade da escolha, por outro impôs um preço à pesquisa: 0 de ter se enveredado por caminhos que não se anunciavam antes de sua realização.

Um desses caminhos foi a descoberta e entendimento dos momentos em que Clemente Pereira esteve sob acusação na Câmara, que a princípio não haviam sido vislumbrados como objeto de investigação. A análise dos anais da Câmara, onde 
ficaram registrados essas acusações mostrou um conteúdo muito rico e pertinente esperamos ter demonstrado - para a investigação. Em suma, porque (1) explicavam muito da trajetória de Clemente Pereira, significando momento de inflexão entre o personagem de 1822, "baluarte da independência", e o jurista que atuaria nos anos seguintes, nos quais essas acusações seriam sempre lembradas; (2) porque eram sintomáticas das disputas diuturnas entre Parlamento e Coroa, tema central da política naqueles anos; (3) porque expunham e eram pautadas por debates jurídicos relevantes, como a responsabilidade dos ministros e os limites do poder moderador e (4) porque - é nossa hipótese - esses processos explicam, junto com outras causas mas com lugar destacado, o fato de ter se obscurecido (então e até hoje) a contribuição que Clemente Pereira deu para a elaboração de um dos pilares desse trabalho, o código criminal.

Sobre o Código Criminal, o foco de nossa análise foi localizar a codificação criminal no Brasil em seu contexto politico e jurídico, e recolocar o projeto de Clemente Pereira em seu contexto.

Em relação ao primeiro movimento, utilizamos largamente o trabalho de Queiroz para entender o direito penal de então e as mudanças que nele se operavam. O projeto de Clemente Pereira pode então ser incorporado à analise que esse autor já fizera dos debates parlamentares à luz dos elementos que davam forma ao direito penal: a autonomia do direito penal, a divisão da matéria em parte geral (princípios) e parte especial, e a separação do direito material e direito processual. Nossa investigação só confirmou as conclusões a que Queiroz já chegara: (1) de que a aprovação de um código apenas criminal foi fruto da urgência dessa legislação para promover a pacificação que esses homens sentiam, e não porque tivessem clareza da autonomia do direito penal; (2) que a separação completa entre direito penal e direito processual também não era ainda tão clara para a maioria dos deputados, inclusive para Clemente Pereira; (3) que a divisão da matéria penal em parte especial, com princípios aplicáveis a toda a legislação, e parte especial era defendida pelo nosso jurista.

Com relação ao segundo movimento, o de resgatar o projeto de Clemente Pereira e trazer alguns elementos de seu conteúdo, foi possível, em primeiro lugar, esclarecer uma confusão presente em boa parte da historiografia: a de que a iniciativa de Clemente Pereira na questão se resumiu à apresentação das bases de 1826. Dos autores 
pesquisados apenas dois fazem menção a esse projeto, mas um deles (Carvalho) não tem por objetivo a investigação jurídica e o outro (Hungria) o faz apenas para fundamentar a superioridade de Vasconcelos, sem incluir nenhum comentário sobre o conteúdo do projeto de Clemente Pereira.

Sobre este, não sendo possível mergulhar em seu conteúdo, procuramos compara sua forma de organização da do Código de 1830 e do projeto de Vasconcelos, seu rival “vencedor". Essa comparação é relevante pois, como afirma Lopes (2004, p. 20), a maneira de se compreender o direito envolve três temas: o conceito de direito, a ordem dos assuntos jurídicos e a justiça. Ao tratar do segundo, afirma que "a ordem dos assuntos define-se em um debate sobre os pontos de partida do raciocínio e o elemento mínimo de um sistema jurídico"139.

Ainda que de maneira bastante sucinta, elencamos os pontos que demonstram que os projetos não eram substancialmente diferentes, ainda que a julgar das escolhas feitas pelos legisladores, o de Vasconcelos fosse mais bem elaborado. $\mathrm{O}$ fato de os projetos serem fruto da mesma visão do direito criminal (então novidade) reforça a necessidade de perseguir suas aproximações e distanciamentos e investigar suas explicações jurídicas, políticas, ideológicas e sociais. O embate de Clemente Pereira e Vasconcelos é muito claro nos processos de responsabilização (ou tentativa de responsabilização) e nos debates sobre o Código Comercial; há um campo aberto para a análise desse embate na formulação de nosso direito penal, que provavelmente explicará - ou trará à luz elementos para explicar - o fato de o projeto de código criminal de Clemente Pereira ter sido relegado às sombras completas, do qual urge ser retirado, objetivo com o qual esperamos ter dado uma contribuição preliminar.

No terceiro capítulo procuramos apenas conectar as linhas traçadas no primeiro capítulo, sobre a trajetória de Clemente Pereira, e a criação do Código Comercial. Seu protagonismo nesse assunto é reconhecido, então nos esforçamos para sumarizar as investigações de Lopes acerca da criação do direito comercial brasileiro, especialmente os debates no parlamento sobre os Tribunais de Comércio, pontos defendidos por Clemente Pereira. Não foi possível analisar esses debates, mas aqui mais uma vez

\footnotetext{
${ }^{139}$ Perspectiva adotada por Queiroz, e detalhada para a moderna codificação criminal. Ver nota 93.
} 
encontramos novamente a polarização entre Clemente Pereira e Vasconcelos; mesmo integrando as fileiras do Partido Conservador eles estarão de lados opostos, o primeiro defendendo a criação de uma jurisdição privativa mais célere e especializada, e o segundo a combatê-la veementemente, argumentando seu caráter de privilégio e possibilidade de cooptação.

Essa oposição muito sumarizada tem como pano de fundo uma questão mais ampla: a prosperidade dos grandes comerciantes, a demandar a codificação do direito comercial e a criação de uma jurisdição mais rápida e eficiente, também pretendia dominar o comércio por meio de privilégios, pois dos atos de comércio participavam fazendeiros e industriais, que seriam julgados pelo aparato judicial que estava sendo discutido.

Mais ainda: Lopes conclui que essas posições representavam embates em torno de uma ideia de modernidade e de Estado nacional. No período de gestação do código o desafio que se colocava aos legisladores era o de "inventar" um Estado nacional "ao mesmo tempo liberal, constitucional, moderno e próspero". Como vimos para o caso do Código Criminal de 1830, as necessidades práticas sentidas pelos responsáveis por essa construção eram canalizadas nos debates sobre legislação, escolhida como via privilegiada de reforma do universo das relações (sociais, políticas, e econômicas).

Esses múltiplos desafios foram cristalizados no debate jurídico, que elegeu alguns temas centrais para dar início à nossa legislação. Entre eles selecionamos alguns: os debates sobre a responsabilidade dos ministros e o poder moderador, a legislação criminal e o código comercial. Representam temas políticos, jurídicos e sociais centrais, e estão entre as primeiras leis promulgadas na nova nação. Seus debates e consequências foram vividos com intensidade por esse magistrado português mas também fluminense, que vivenciou e testemunhou as mudanças profundas que esse período trouxe não só para a politica, o direito, a economia e a sociedade, mas para a própria visão de mundo dos homens que o viveram. Características que fazem desse período um dos mais difíceis de se estudar, mas também dos mais fascinantes; o preço a pagar pela ousadia de tentar fazê-lo vale a pena. 


\section{BIBLIOGRAFIA}

BITTENCOURT, Vera Lucia Nagib (2006). De alteza real a imperador: o governo do Príncipe D. Pedro, de abril de 1821 a outubro de 1822. São Paulo: Universidade de São Paulo (tese).

BRAVO LIRA, Bernardino (2004). "Dos vertientes de la codificación: em torno al bicentenário de los códigos penal de austria (1803) y civil em Francia (1804)". In La codificacion: raices e prospectiva: la coficiacion em America. (Vários) Buenos Aires: El derecho.

CALDEIRA, Jorge (1999). Diogo Antonio Feijó (Coleção Formadores do Brasil). São Paulo: Editora 34.

CARVALHO, José Murilo de (1996). A Construção da ordem: a elite política imperial. Rio de Janeiro: Ed. da UFRJ / Relume Dumará.

(1999). Bernardo Pereira de Vasconcelos (Coleção Formadores do Brasil). São Paulo: Editora 34.

CARVALHO, José Vilhena de (2002). José Clemente Pereira: baluarte da independência e do progresso do Brasil. Vida e obra. Rio de Janeiro: J.V.Carvalho.

CARVALHO, Manuel Emílio Gomes de (2003). Os deputados Brasileiros nas Cortes gerais de 1821. Brasília: Edições do Senado Federal.

DANTAS, Monica Duarte (no prelo) "Introdução - Revoltas, motins, revoluções: das Ordenações ao Código criminal". In Revoltas, motins, revoluções: homens livres pobres e libertos no Brasil do século XIX. (idem) São Paulo: Alameda Editorial.

DOLHNIKOFF, Miriam (2008). "Império e governo representativo: uma releitura". In Caderno CRH, Salvador, V. 21, n. 52, p. 13 a 23, Jan/Abr 2008.

FRAGOSO, João Luís (1998). Homens de grossa ventura: acumulação e hierarquia na praça mercantil do Rio de Janeiro (1790-1830). Rio de Janeiro: Civilização Brasileira.

HESPANHA, Antonio Manuel (2004). Guiando a mão invisível. Direitos, Estado e Lei no liberalismo monárquico português. Coimbra: Almedina. (1993). "Da iustitia à disciplina; textos, poder e politica penal no Antigo Regime". In Justiça e litigiosidade: história e prospectiva. Lisboa: Fundação Calouste Gulbekian. 
HOLANDA, Sérgio Buarque de (2003). História Geral da Civilização Brasileira. Tomo II, Vol. 3. Rio de Janeiro: Bertrand Brasil.

HUNGRIA, Nelson (1977). "Comentários ao Código Criminal”. Rio de Janeiro: Revista Forense.

LISBOA, José da Silva (1826). História dos Principais Sucessos Políticos do Império do Brasil. Rio de Janeiro: Typographia Imperial e Nacional.

LOPES, José Reinaldo de Lima (2002). O direito na história. São Paulo: Max Limonad.

(2003). "Iluminismo e jusnaturalismo no ideário dos juristas da primeira metade do século XIX”. In: Brasil: formação do Estado e da Nação. (Istvan Jancsó, org) São Paulo/Ijuí: Fapesp/Hucitec/Unijuí. (2004). As palavras e a lei: direito, ordem e justiça na história do pensamento jurídico moderno. São Paulo: Ed. 34/Edesp. (2007a) "Consultas da Seção de Justiça do Conselho de Estado (1842-1889): a formação da cultura jurídica brasileira. In Almanack Brasiliense $n^{\circ} 5$. (2007b) “A formação do direito comercial brasileiro: a criação dos tribunais de comércio do Império". In Cadernos Direito GV, v. 4 n.6: novembro 2007.

LOPES, José Reinaldo de Lima; QUEIROZ, Rafael Mafei Rabelo; ACCA, Thiago dos Santos (2009). Curso de História do Direito. Rio de janeiro: forense; São Paulo: Método.

LYNCH, Christian Edward Cyrill (2005). "O discurso político monarquiano e a recepção do conceito de Poder Moderador no Brasil (1822-1824)". In Revista Dados, julho-setembro, ano/vol. 48, número 003.

http://redalyc.uaemex.mx/pdf/218/21848306.pdf

MATTOS, Ilmar Rohloff de (2004). O tempo saquarema. A formação do Estado Imperial. São Paulo: Hucitec.

MONTEIRO, Tobias (1981). História do Império: a elaboração da independência. Tomo 2. Belo Horizonte: Ed. Itatiaia; São Paulo: Ed. da Universidade de São Paulo.

(1982). História do Império: primeiro Reinado. V.2. Belo Horizonte: Ed. Itatiaia; São Paulo: Ed. da Universidade de São Paulo. 
NEVES, Lúcia Maria Bastos Pereira das (2003). Corcundas, Constitucionais e Pés de chumbo: a cultura política da independência (1820-1822). Rio de Janeiro: FAPERJ: Revan.

OLIVEIRA, Cecília Helena L. de Salles (1999). A astúcia Liberal. Relações de mercado e projetos políticos no Rio de Janeiro (1820 - 1824). Bragança Paulista, Edusf/Ícone.

PIERANGELLI, José Henrique (2001). Códigos penais do Brasil: evolução histórica. São Paulo: Ed. Revista dos Tribunais.

PIMENTA, João Paulo Garrido (2008). “A independência do Brasil e o liberalismo português: um balanço da produção acadêmica". In Revista de História Iberoamericana, 2008, Vol. 1.

PIÑEIRO, Théo Lobarinhas (2002). Os simples comissários: negociantes e política no Brasil Império. Niterói: Universidade Federal Fluminense (tese).

PORTO ALEGRE, Manuel de Araújo (1991). Correspondência com Paulo Barbosa da Silva. Coleção Afrânio Peixoto, da Academia Brasileira de Letras. Rio de Janeiro. Organização Arnaldo Niskier.

QUEIROZ, Rafael Mafei Rabelo (2009). A teoria penal de P.J.A. Feuerbach e os juristas brasileiros do século XIX: a construção do direito penal contemporâneo na obra de P.J.A. Feuerbach e sua consolidação entre os penalistas do Brasil. São Paulo: Universidade de São Paulo (tese).

RANGEL, Alberto (1937). No rolar do tempo: opiniões e testemunhos respingados no arquivo do Orsay - Paris. (Coleção Documentos Brasileiros nº 6). Rio de Janeiro: Livraria José Olympio Editora.

ROCHA, Antonio Penalves (2001). Visconde de Cairu (Coleção Formadores do Brasil). São Paulo: Editora 34.

RODRIGUES, José Honório (1975). Independência: revolução e contrarevolução. A liderança Nacional. Vol. 5. Rio de Janeiro: Editora da Universidade de São Paulo/Livraria Francisco Alves Editora S.A.

(1978). Conselho de Estado: quinto poder? Brasília: Centro Gráfico do Senado Federal.

(1973-1978). Atas do Conselho de Estado. Brasília: Senado

Federal. 13 volumes.

SILVA, J. M. Pereira da (1865). História da fundação do Império Brasileiro. Rio de Janeiro: BL Garnier Editor. Volume 05. 
SLEMIAN, Andréa (2006a). Sob o império das leis: Constituição e unidade nacional na formação do Brasil (1822 - 1834). São Paulo: Universidade de São Paulo (tese).

(2006b). "Seriam todos cidadãos? Os impasses na construção da cidadania nos primórdios do constitucionalismo no Brasil (1823-1824)". In Independência: história e historiografia. (István Jancsó, org.) São Paulo: Fapesp/Hucitec. (2008). “A nação independente, um novo ordenamento jurídico: a criação dos Códigos Criminal e do Processo Penal na primeira década do Império do Brasil”. In: Brasileiros e Cidadãos: modernidade política (1822 - 1930). (Gladys Sabina Ribeiro, org) São Paulo: Alameda.

SOUZA, Osvaldo Tarquínio de (1988a). A vida de D. Pedro I. História dos Fundadores do Império do Brasil. Belo Horizonte: Itatiaia - São Paulo: EDUSP. (1988b). José Bonifácio. Belo Horizonte: Itatiaia - São Paulo: EDUSP. 


\section{OBSERVAÇÕES}

As atas das sessões do Parlamento foram consultadas pela internet;

- na página eletrônica da Câmara dos Deputados e no texto aparecem citadas com a abreviatura APB (Anais do Parlamento Brasileiro), seguida da data e página.

http://www2.camara.gov.br/documentos-e-pesquisa/publicacoes

- na página eletrônica do Senado e no texto aparecem citadas com a abreviatura AS (Anais do Senado), seguida da data e página.

http://www.senado.gov.br/publicacoes/anais/asp/AP_Apresentacao.asp

Projetos de lei: os dois projetos de código criminal abordados nesse trabalho não tiveram suas íntegras reproduzidas nas atas das sessões do Parlamento.

- O projeto de Bernardo Pereira de Vasconcelos, de 04 de maio de 1827 foi impresso em avulso e obtido junto ao Centro de Documentação e Informação (CEDI) da Câmara dos Deputados.

- O projeto de Clemente Pereira, de 16 de maio de 1827, foi publicado pela Tipografia Imperial e Nacional, em 1827, e está registrado em microfilme (OR 00168 [2) disponível na Biblioteca Nacional, no setor de obras raras.

As informações biográficas têm por fonte:

- a página do Senado para aqueles que ocuparam o cargo de Senador: http://www.senado.gov.br/senadores/periodos/Imperio.shtm

- os livros da coleção "Formadores do Brasil" nos casos de Bernardo Pereira de Vasconcelos, Diogo Antônio Feijó e José da Silva Lisboa, citados na bibliografia.

- subsidiariamente, a tese de doutorado "Sob o Império das leis: Constituição e unidade nacional na formação do Brasil (1822-1834)" de Andrea Slemian.

- no caso de outras fontes a indicação está nas notas de rodapé. 


\section{ANEXO 01 ${ }^{140}$ \\ Índice do Projeto de José Clemente Pereira apresentado em 03 de junho de 1826 ("Bases") ${ }^{141}$}

Livro primeiro - Dos crimes e das penas

Titulo I - Dos crimes em geral e seus autores

Capitulo 1 - Dos crimes

Capitulo II - Dos autores

Titulo II - Das penas

Capitulo I - Das penas em geral

Capitulo II - Da pena de morte

Capitulo III - Da pena de desnaturalização

Capitulo IV - Da pena de trabalhos públicos

Capitulo V - Da pena de degredo

Capitulo VI - Da suspensão dos direito políticos

Capitulo VII - Da multa

\footnotetext{
${ }^{140}$ Os anexos reproduzem os índices dos três projetos, uma vez que a análise conjunta deles se restringiu a sua organização e sistemática.

${ }^{141}$ Anais da Câmara dos Deputados, p. 15. O primeiro artigo previa: "O código criminal do império do Brasil será dividido em dois livros: o primeiro tratará dos crimes e das penas, e o segundo conterá a ordem do processo criminal".
} 


\section{ANEXO 02 \\ Índice do Projeto de Código Criminal apresentado por José Clemente \\ Pereira em 16 de maio de 1827}

Título I - Dos crimes em geral e de seus autores

Capítulo I - Dos crimes

Capítulo II - dos autores dos crimes

Título II - Das penas

Capítulo I - Das penas em geral

Capítulo II - Da pena de morte

Capítulo III - da pena de trabalhos públicos

Capítulo IV - Da pena de prisão

Capítulo V - Da pena de multa

Título III - Dos crimes contra a religião do império

Título IV - Das injurias feitas ao imperador, e Família Imperial

Título V - Dos crimes contra as garantias da constituição política do império

Título V - Dos crimes contra a segurança externa do Império

Capítulo I - dos que auxiliam nações estrangeiras em dano ao Império

Capítulo II - Dos que praticam atos hostis, ou indevidos, contra nações amigas, ou neutras

Capítulo III - Das ofensas e injúrias feitas aos representantes das nações estrangerias, aos reféns, parlamentários, prisioneiros de guerra, e aos que tiverem salvo conduto Imperial

Capítulo. IV - Dos crimes de pirataria

Título VI - Dos crimes contra a segurança interna do império

Capítulo I - Do crime de conspiração

Capítulo II - Do crime de sedição

Título VII - Das sociedades secretas

Título VIII - Dos crimes de resistência publica

Título XIX - Dos crimes de desobediência aos mandados das autoridades constituídas

Título X - Da falta de respeito devido aos que exercem o poder

Título XII - Dos crimes contra a tranquilidade pública

Capítulo I - Dos pasquins

Capítulo II - Do uso de armas proibidas

Capítulo III - Do crime de desafio

Capítulo IV - Do crime de tumulto

Capítulo V - do crime de assuada 
Título XIII - Das prevaricações, abusos e omissões dos empregados públicos

Capítulo I - Do crime de peculato

Capítulo II - Do crime de peita

Capítulo III - Do crime de concussão

Capítulo IV - Da falta de exacção dos Empregados Públicos no cumprimento de seus deveres

Capítulo V - Do excesso de autoridade

Título XIV - Do crime de moeda falsa

Título XV - Do crime de falsidade

Título XVI - Do crime de perjúrio

Título XVII - Do crime de calúnia

Título XVIII - Do crime de injuria

Título XIX - Do crime de sodomia, bestialidade e molicie

Título XX - Do crime de bigamia

Título XXI - Do crime de adultério

Título XXII - Do crime de rapto e estupro

Título XXIII - Do crime de lenocínio

Título XXIV - Do crime de homicídio

Título XXV - Do crime de ferimentos

Título XXVI - Do crime de furto

Título XXVII - Do crime de quebra dolosa

Título XXVIII - Dos crimes contra o comércio público

Capítulo I - Dos que falsificam mercadorias para vender

Capítulo II - Dos que usam pesos, medidas, ou balanças falsas, ou falsificadas

Título XXIX - Dos que usam nomes, títulos, uniformes, condecorações ou distintivos indevidos

Título XXX - Do dano causado por culpa ou dolo

Título XXXI - Dos vadios, mendigos e jogadores

Capítulo I - Dos vadios

Capítulo II - dos mendigos 
Capítulo III - Dos jogadores

Título XXXII - Das contravenções de policia e boa ordem pública

Título XXXIII - Disposições gerais 


\section{ANEXO 03 \\ Índice do Projeto de Código Criminal Apresentado por Bernardo \\ Pereira de Vasconcelos em 04 de maio de 1827.}

Titulo 1 - Dos crimes e penas em geral

Titulo 2 - Dos crimes policiais

Titulo 3 - Dos crimes particulares

Título 4 - Dos delitos públicos

Título 5 - Disposições finais
Cap. 1 - Dos criminosos

Cap. 2 - Dos delitos justificados

Cap. 3 - Das circ. agravantes e atenuantes dos delitos

Cap. 4 - Da satisfação

Cap. 5 - Das penas

Cap. 6 - Da prescrição e perdão das penas Único

Cap. 1 - Dos crimes contra as pessoas

Cap. 2 - Dos delitos morais

Cap. 3 - Dos crimes contra a honra

Cap. 4 - Dos crimes contra as pessoas e contra a honra

Cap. 5 - Dos crimes contra a propriedade

Cap. 6 - Dos crimes contra a pessoa e a propriedade

Cap. 7 - Dos crimes contra o estado doméstico e civil

Cap. 1 - Dos crimes contra a ordem interior do Império Cap. 2 - Dos delitos contra o tesouro público

Cap. III - Dos crimes contra a segurança int. do império

Cap. IV - Dos crimes contra a segurança ext. do império

Crimes militares e comerciais não serão incluídos 